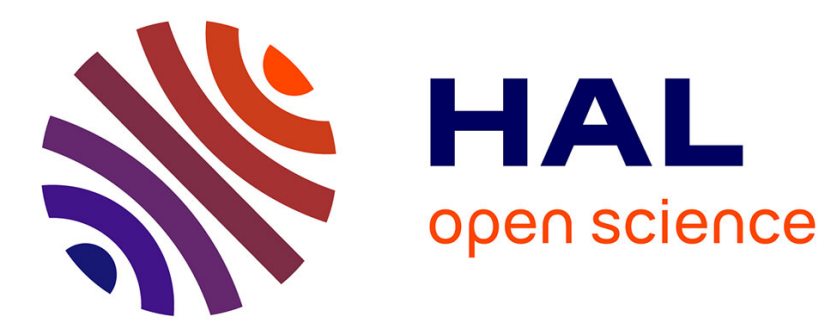

\title{
Nitrosyl linkage photoisomerization in heteroleptic fluoride ruthenium complexes derived from labile nitrate precursors
}

Artem A Mikhailov, Vladislav Yu. Komarov, Denis P Pishchur, Dominik Schaniel, Gennadiy A Kostin

\section{To cite this version:}

Artem A Mikhailov, Vladislav Yu. Komarov, Denis P Pishchur, Dominik Schaniel, Gennadiy A Kostin. Nitrosyl linkage photoisomerization in heteroleptic fluoride ruthenium complexes derived from labile nitrate precursors. New Journal of Chemistry, 2021, 45 (18), pp.8192-8202. 10.1039/D1NJ01038G . hal-03401192

\section{HAL Id: hal-03401192 \\ https://hal.univ-lorraine.fr/hal-03401192}

Submitted on 25 Oct 2021

HAL is a multi-disciplinary open access archive for the deposit and dissemination of scientific research documents, whether they are published or not. The documents may come from teaching and research institutions in France or abroad, or from public or private research centers.
L'archive ouverte pluridisciplinaire HAL, est destinée au dépôt et à la diffusion de documents scientifiques de niveau recherche, publiés ou non, émanant des établissements d'enseignement et de recherche français ou étrangers, des laboratoires publics ou privés. 


\section{Nitrosyl linkage photoisomerization in heteroleptic fluoride ruthenium complexes derived from labile nitrate precursors}

Artem A. Mikhailov ${ }^{a}$, Vladislav Yu. Komarova ${ }^{a}$ Denis P. Pishchur ${ }^{a}$, Dominik Schaniel ${ }^{b}$ and Gennadiy A. Kostin ${ }^{a}$

a Nikolaev Institute of Inorganic Chemistry, Siberian Branch of the Russian Academy of Sciences, 3 Acad. Lavrentiev Avenue, Novosibirsk 630090, Russian Federation

${ }^{\mathrm{b}}$ Université de Lorraine, CNRS, CRM2, UMR 7036, Nancy 54000, France

\section{Abstract}

Four complexes with trans-ON-Ru-F coordinate were synthesized from the corresponding nitrate precursors. The treatment of fac-[RuNO$\left.\left(\mathrm{NH}_{3}\right)_{2}\left(\mathrm{NO}_{3}\right)_{3}\right]$ with hydrofluoric acid results in the substitution of the labile nitrate ligands by $\mathrm{H}_{2} \mathrm{O}$ and $\mathrm{F}^{-}$, whereas the treatment of trans-(NO,NO$)$-cis- $\left(\mathrm{NH}_{3}, \mathrm{NH}_{3}\right)-\left[\mathrm{RuNO}\left(\mathrm{NH}_{3}\right)_{2} \mathrm{Py}_{2}\left(\mathrm{NO}_{3}\right)\right]\left(\mathrm{NO}_{3}\right)_{2} \cdot \mathrm{H}_{2} \mathrm{O}$ leads to additional pyridine ligand elimination. The structures of the four complexes were characterized by $\mathrm{X}$ ray diffraction: $\operatorname{trans}(\mathrm{NO}, \mathrm{F})-\operatorname{cis}\left(\mathrm{NH}_{3}, \mathrm{NH}_{3}\right)-\left[\mathrm{RuNO}\left(\mathrm{NH}_{3}\right)_{2}\left(\mathrm{H}_{2} \mathrm{O}\right)_{2} \mathrm{~F}\right] \mathrm{SiF} \mathrm{F}_{6} \quad$ (I), $\operatorname{trans}(\mathrm{NO}, \mathrm{F})-\operatorname{cis}\left(\mathrm{NH}_{3}, \mathrm{NH}_{3}\right)-$ $\left[\operatorname{RuNO}\left(\mathrm{NH}_{3}\right)_{2} \mathrm{Py}\left(\mathrm{NO}_{3}\right) \mathrm{F}_{2} \mathrm{SiF}_{6} \cdot \mathrm{H}_{2} \mathrm{O}\right.$ (II), $\operatorname{trans}(\mathrm{NO}, \mathrm{F})-\operatorname{cis}\left(\mathrm{NH}_{3}, \mathrm{NH}_{3}\right)-\left[\mathrm{RuNO}\left(\mathrm{NH}_{3}\right)_{2} \mathrm{Py}\left(\mathrm{H}_{2} \mathrm{O}\right) \mathrm{F}\right]\left(\mathrm{ClO}_{4}\right)_{2} \quad$ (III) and $\operatorname{trans}(\mathrm{NO}, \mathrm{F})-\operatorname{cis}\left(\mathrm{NH}_{3}, \mathrm{NH}_{3}\right)-\left[\left(\mathrm{RuNOPy}\left(\mathrm{NH}_{3}\right)_{2} \mathrm{~F}\right)_{2}\left(\mu-\mathrm{O}_{2} \mathrm{H}_{3}\right)\right]\left(\mathrm{ClO}_{4}\right)_{3}$ (IV). Upon light irradiation, the complexes I, II and III show reversible formation of metastable linkage isomers MS1 and MS2 with remarkable thermal stability of both isomers. Moreover, complexes I and III show the highest thermal stability of the MS2 isomers, which leads to a higher photogeneration temperature of MS1 via the GS $\rightarrow$ MS2 $\rightarrow$ MS1 mechanism. Such excellent properties of the resulting materials can be used in a design of molecular based data storage devices.

\section{Introduction}

Photoinduced linkage isomerism of ruthenium nitrosyl complexes is an intriguing property, which can find many potential applications in materials combining switchable photochromism and nonlinear optical (NLO), magnetic or other properties ${ }^{1-5}$. Since NO release from nitrosyl ruthenium complexes in solution occurs under the light excitation, these complexes are attractive species for photodynamic therapy applications ${ }^{6}$. In general, the investigation and searching for novel nitric oxide donors is an important field due to known biological properties of $\mathrm{NO}^{7-10}$. Recently, many researches emphasize significance of investigation of new nitric oxide carriers with respect to the fight with COVID-19 ${ }^{11-14}$. The mechanism of nitric oxide photo-release in solution can be schematically described as a following ${ }^{15}$ :

$$
\mathrm{L}_{5} \mathrm{Ru}^{2+}-\mathrm{NO}^{+} \rightarrow \mathrm{L}_{5} \mathrm{Ru}^{2+}-\eta^{2}-\left(\mathrm{NO}^{+}\right)+\text {Solvent } \rightarrow \mathrm{L}_{5} \mathrm{Ru}^{3+} \text { (Solvent) }+\mathrm{NO}^{0},
$$

where metastable linkage isomers (MS2 in current case) are intermediates in this reaction, and since for the NO release two photons are needed to be absorbed by the ruthenium complex, longer lifetime of the metastable states may provide better efficiency of nitric oxide release. 
In solid state, the photoexcitation of nitrosyl complexes transforms the Ru-NO linkage (ground state, GS) to the metastable linkage isomers Ru-ON (MS1) or/and Ru- $\eta^{2}$-(NO) (MS2). Such reactions usually occur at low temperatures $(80-100 \mathrm{~K})$ with the thermally or photoinduced reverse transformation ${ }^{16-18}$. Higher thermal stability of the metastable states facilitates the usage of such molecular switches in design of molecular based data storage devices ${ }^{5}$. The specific temperature ( $T_{d}$, decay temperature) at which the rate of reverse transformation equals $10^{-3} \mathrm{~s}^{-1}$ earlier was suggested as a convenient parameter to compare the stability of linkage isomers of different complexes ${ }^{19}$. Our previous investigations clearly demonstrate that complexes with trans-coordinate ON-Ru-F have the highest thermal stability of metastable isomers MS1 among all known nitrosyl complexes ${ }^{20-22}$. Cationic complexes trans-[RuNOL $\left.L_{4} \mathrm{~F}\right]^{2+}\left(\mathrm{L}=\mathrm{NH}_{3}, \mathrm{Py}\right)$ with different counterions exhibit decay temperatures of the MS1 in the range 289 - $307 \mathrm{~K}$ and the main reason of such stability is the high electronegativity of trans-to-NO ligand, which favors the stability of the MS1 isomer 2,20,23,24. By changing the counterion the thermal stability of the linkage isomers can be influenced, thereby reaching record high decay temperatures ${ }^{21}$. Therefore, in the framework of our investigations, we aim now to study the influence of changing equatorial ligands on the thermal stability of the linkage isomers MS1 and MS2.

For the preparation of complexes trans- $\left[\mathrm{RuNOL}_{4} \mathrm{~F}\right]^{2+}$ we exploited the simple technique based on the substitution of trans-to-NO hydroxo-ligand. The lability of hydroxo-ligand in trans-position to NO in acidic media often is used for the modifications of complexes and explained by both the protonation of $\mathrm{OH}^{-}$and strong transinfluence of NO ligand ${ }^{25-27}$. Arion and co-workers showed that the reaction of $\left[\mathrm{RuNOCl}_{5}\right]^{2-}$ anion with bidentate amino acids results only in one isomer, namely mer-Cl-trans-(NO,O)-[RuCl$\left(\mathrm{L}_{3}\right) \mathrm{NO}^{-}{ }^{26}$. The labilizing transinfluence of the NO was also noted in the reactions of chlorine-to-OH substitution ${ }^{28-30}$. Quantum chemical calculations performed by the Malfant group clearly indicate that the substitution of trans-to-NO chloride is more thermodynamically favorable - the resulting isomer has the lowest Gibbs energy compared with one for cis-chloride substitution ${ }^{28}$. Nevertheless, there are also some examples where the trans-influence of the nitrosyl group is not so obvious. The reaction of trans- $(\mathrm{NO}, \mathrm{OH})-\left[\mathrm{RuNO}\left(\mathrm{NO}_{2}\right)_{4} \mathrm{OH}\right]^{2-}$ with $20 \%$ ammonia results in the substitution of two $\mathrm{NO}_{2}^{-}$ligands with the formation of trans-(NO,OH)-cis- $\left(\mathrm{NH}_{3}, \mathrm{NH}_{3}\right)-\left[\mathrm{Ru}(\mathrm{NO})\left(\mathrm{NO}_{2}\right)_{2}\left(\mathrm{NH}_{3}\right)_{2} \mathrm{OH}\right]$ complex with unchanged ON-Ru-OH coordinate ${ }^{31}$. The reaction of $f a c-\left[\mathrm{RuNO}\left(\mathrm{NH}_{3}\right)_{2}\left(\mathrm{NO}_{3}\right)_{3}\right]$ with pyridine results in trans- $\left(\mathrm{NO}, \mathrm{NO}_{3}\right)$-cis- $\left(\mathrm{NH}_{3}, \mathrm{NH}_{3}\right)-\left[\mathrm{RuNO}\left(\mathrm{NH}_{3}\right)_{2} \mathrm{Py}_{2}\left(\mathrm{NO}_{3}\right)\right]\left(\mathrm{NO}_{3}\right)_{2} \cdot \mathrm{H}_{2} \mathrm{O}$ complex with high yield $(84 \%)^{32}$, while the reaction of $\mathrm{fac}_{-}\left[\mathrm{RuNOP}_{2}\left(\mathrm{NO}_{3}\right)_{3}\right]$ with pyridine in the same conditions gives fac-(Py)-trans-(NO,OH)$\left[\mathrm{RuNOP}_{3} \mathrm{NO}_{3}(\mathrm{OH})\right]^{+}$with the aquation of trans-to-NO ligand ${ }^{33}$. Because of the low binding constants the nitrate ligands are good outgoing groups and suitable for ligand replacement ${ }^{34}$ and the above-mentioned nitrate complexes are good precursors for the fluoride ligand substitution.

Thus, in the present work we examined the reactions of fac- $\left[\mathrm{RuNO}\left(\mathrm{NH}_{3}\right)_{2}\left(\mathrm{NO}_{3}\right)_{3}\right]$ and trans- $\left(\mathrm{NO}, \mathrm{NO}_{3}\right)$-cis$\left(\mathrm{NH}_{3}, \mathrm{NH}_{3}\right)-\left[\mathrm{RuNO}\left(\mathrm{NH}_{3}\right)_{2} \mathrm{Py}_{2}\left(\mathrm{NO}_{3}\right)\right]\left(\mathrm{NO}_{3}\right)_{2} \cdot \mathrm{H}_{2} \mathrm{O}$ with hydrofluoric acid, identified the products of the reactions and investigated the formation and properties of photoinduced linkage isomers in the resulted compounds. 


\section{Experimental}

The complexes fac- $\left[\mathrm{RuNO}\left(\mathrm{NH}_{3}\right)_{2}\left(\mathrm{NO}_{3}\right)_{3}\right]$ 35 and trans- $\left(\mathrm{NO}, \mathrm{NO}_{3}\right)-c i s-\left(\mathrm{NH}_{3}, \mathrm{NH}_{3}\right)$ $\left[\mathrm{RuNO}\left(\mathrm{NH}_{3}\right)_{2} \mathrm{Py}_{2}\left(\mathrm{NO}_{3}\right)\right]\left(\mathrm{NO}_{3}\right)_{2} \cdot \mathrm{H}_{2} \mathrm{O}^{32}$ were prepared according to the methods described earlier.

\section{Synthesis of trans(NO,F)-cis $\left(\mathrm{NH}_{3}, \mathrm{NH}_{3}\right)-\left[\mathrm{RuNO}\left(\mathrm{NH}_{3}\right)_{2}\left(\mathrm{H}_{2} \mathrm{O}\right)_{2} \mathrm{~F}\right] \mathrm{SiF}$ (I)}

$3.65 \cdot 10^{-4}$ moles of $f a c$ - $\left[\mathrm{RuNO}\left(\mathrm{NH}_{3}\right)_{2}\left(\mathrm{NO}_{3}\right)_{3}\right]$ were heated in $\sim 10 \mathrm{ml}$ of concentrated hydrofluoric acid $(40 \%)$ at $100^{\circ} \mathrm{C}$ for $6 \mathrm{~h}$. The treatment was performed in a closed polytetrafluoroethylene (PTFE) beaker on oil bath. After the treatment the open beaker was placed in a glass desiccator and left until yellow crystals (also suitable for Xray diffraction) were formed (around 5 days). The $\mathrm{SiF}_{6}{ }^{2-}$ anion is formed by the reaction of HF with silicon of the glass desiccator during crystallization. The crystals were washed by diethyl ether on a glass filter. The yield is $90 \%$. The powder XRD patterns of the bulk sample correspond to the theoretical patterns calculated from the crystal structure determined by single-crystal XRD. Elemental analysis for $\mathrm{F}_{7} \mathrm{H}_{10} \mathrm{~N}_{3} \mathrm{O}_{3}$ RuSi, calculated/found (\%): $\mathrm{H}$ 2.8/2.8, N 11.6/11.5. IR bands at room temperature, $\mathrm{cm}^{-1}: 3146$ [v(N-H)]; 1910 [v(NO)]; 1574, 1337 [ $\left.\delta(\mathrm{H}-\mathrm{N}-\mathrm{H})\right]$; $739[\mathrm{v}(\mathrm{Si}-\mathrm{F})]$.

\section{Synthesis of $\operatorname{trans}(\mathrm{NO}, \mathrm{F})-\operatorname{cis}\left(\mathrm{NH}_{3}, \mathrm{NH}_{3}\right)-\left[\mathrm{RuNO}\left(\mathrm{NH}_{3}\right)_{2} \mathrm{Py}\left(\mathrm{NO}_{3}\right) \mathrm{F}\right]_{2} \mathrm{SiF}_{6} \cdot \mathrm{H}_{2} \mathrm{O}$ (II)}

2.1·10-4 moles of trans- $\left(\mathrm{NO}, \mathrm{NO}_{3}\right)$-cis- $\left(\mathrm{NH}_{3}, \mathrm{NH}_{3}\right)-\left[\mathrm{RuNO}\left(\mathrm{NH}_{3}\right)_{2} \mathrm{Py}{ }_{2}\left(\mathrm{NO}_{3}\right)\right]\left(\mathrm{NO}_{3}\right)_{2} \cdot \mathrm{H}_{2} \mathrm{O}$ were heated in $\sim 10 \mathrm{ml}$ of concentrated hydrofluoric acid $(40 \%)$ at $100{ }^{\circ} \mathrm{C}$ for $20 \mathrm{~h}$. The treatment was performed in a closed polytetrafluoroethylene (PTFE) beaker on oil bath. At the end of the heating the beaker was opened and HF was evaporated up to $\sim 3 \mathrm{ml}$ of the solution. The resulting solution was transferred to the glass beaker and orange crystals (also suitable for X-ray diffraction) were formed readily. The $\mathrm{SiF}_{6}{ }^{2-}$ anion is formed by the reaction of $\mathrm{HF}$ with silicon of the glass beaker during crystallization. In $24 \mathrm{~h}$ the crystals were washed by minima of water and diethyl ether on a glass filter. The yield is $70 \%$. The powder XRD patterns of the bulk sample correspond to the theoretical patterns calculated from the crystal structure determined by single-crystal XRD. Elemental analysis for $\mathrm{C}_{10} \mathrm{H}_{26} \mathrm{~F}_{8} \mathrm{~N}_{10} \mathrm{O}_{10} \mathrm{Ru}_{2} \mathrm{Si}$, calculated/found (\%): C 14.5/14.5, H 3.2/3.1, N 16.9/16.4. IR bands at room temperature, $\mathrm{cm}^{-1}: 3565[\mathrm{v}(\mathrm{O}-\mathrm{H})] ; 3218[\mathrm{v}(\mathrm{N}-\mathrm{H})] ; 1926$ [v(NO)]; $1647[\delta(\mathrm{H}-\mathrm{O}-\mathrm{H})] ; 1611[\delta(\mathrm{H}-\mathrm{N}-\mathrm{H})] ; 1506,1276$ $\left[\mathrm{v}\left(\mathrm{NO}_{3}\right)\right] ; 998[\delta(\mathrm{O}-\mathrm{N}-\mathrm{O})] ; 736[\mathrm{v}(\mathrm{Si}-\mathrm{F})]$.

\section{Synthesis of trans(NO,F)-cis $\left(\mathrm{NH}_{3}, \mathrm{NH}_{3}\right)-\left[\mathrm{RuNO}\left(\mathrm{NH}_{3}\right)_{2} \mathrm{Py}\left(\mathrm{H}_{2} \mathrm{O}\right) \mathrm{F}\right]\left(\mathrm{ClO}_{4}\right)_{2}$ (III)}

$2 \cdot 10^{-4}$ moles of the trans- $\left(\mathrm{NO}, \mathrm{NO}_{3}\right)-$ cis- $\left(\mathrm{NH}_{3}, \mathrm{NH}_{3}\right)-\left[\mathrm{RuNO}\left(\mathrm{NH}_{3}\right)_{2} \mathrm{Py} 2\left(\mathrm{NO}_{3}\right)\right]\left(\mathrm{NO}_{3}\right)_{2} \cdot \mathrm{H}_{2} \mathrm{O}$ were heated in $\sim 10 \mathrm{ml}$ of concentrated hydrofluoric acid $(40 \%)$ at $100{ }^{\circ} \mathrm{C}$ for $20 \mathrm{~h}$. The treatment was performed in a closed polytetrafluoroethylene (PTFE) beaker on oil bath. At the end of the heating the beaker was opened and HF was evaporated resulting in orange viscous residue. The residue was washed with a few portions of diethyl ether to obtain bright yellow powder, which was not stable without ether. $1 \mathrm{ml}$ of concentrated $\mathrm{HClO}_{4}(70 \%)$ was added to the yellow powder. In one week suitable crystals for X-ray diffraction were formed. The resulting crystals were also poorly stable without a solvent. The yellow powder was precipitated by the excess of diethyl ether and thoroughly washed by the ether on a glass filter. We succeeded to obtain the stable yellow solid with $25 \%$ yield. 
The powder XRD patterns of the bulk sample correspond to the theoretical patterns calculated from the crystal structure determined by single-crystal XRD. Elemental analysis for $\mathrm{C}_{5} \mathrm{H}_{13} \mathrm{Cl}_{2} \mathrm{FN}_{4} \mathrm{O}_{10} \mathrm{Ru}$, calculated/found (\%): $\mathrm{C}$ 12.5/12.7, H 2.7/2.6, N 11.7/11.1. IR bands at room temperature, $\mathrm{cm}^{-1}: 3310$ [v(N-H)]; 1918 [v(NO)]; 1615, 1455, $1317[\delta(\mathrm{H}-\mathrm{N}-\mathrm{H})] ; 1099[\mathrm{v}(\mathrm{Cl}-\mathrm{O})]$.

\section{Preparation of trans(NO,F)-cis $\left(\mathrm{NH}_{3}, \mathrm{NH}_{3}\right)-\left[\left(\operatorname{RuNOPy}\left(\mathrm{NH}_{3}\right)_{2} \mathrm{~F}\right)_{2}\left(\mu-\mathrm{O}_{2} \mathrm{H}_{3}\right)\right]\left(\mathrm{ClO}_{4}\right)_{3}(\mathrm{IV})$ single crystals}

$50 \mathrm{mg}$ of trans(NO,F)-cis $\left(\mathrm{NH}_{3}, \mathrm{NH}_{3}\right)-\left[\mathrm{RuNO}\left(\mathrm{NH}_{3}\right)_{2} \mathrm{Py}\left(\mathrm{H}_{2} \mathrm{O}\right) \mathrm{F}\right]\left(\mathrm{ClO}_{4}\right)_{2}$ (III) powder was dissolved in minimum volume of water. Slow evaporation at room temperature gave yellow crystals suitable for $\mathrm{X}$-ray diffraction. Further evaporation of the solution resulted in the formation of viscous hygroscopic solid which was not identified. Since in this way only few isolated crystals of IV were obtained, the analysis of the bulk sample was not performed.

\section{Single-crystal X-Ray diffraction}

Single crystal X-ray diffraction data of complexes I-III were collected on a Bruker Apex Duo diffractometer with CCDs using graphite-monochromated MoKa radiation $\left(\lambda=0.71073 \AA\right.$ ) via $0.5^{\circ} \omega$ - and $\phi$-scan techniques. Single crystal X-ray diffraction data of complex IV was collected on a Rigaku Oxford Diffraction SuperNova fourcircle diffractometer with a molybdenum anode (MoK $\alpha, \lambda=0.71073 \AA$ ) radiation and CCD Atlas detector. Reduction of the experimental data was performed using the APEX2 suite. The structures were solved by SHELXT and refined by the full-matrix least-squares technique SHELXL ${ }^{36}$ assisted with the Olex2 GUI ${ }^{37}$. The atomic displacement parameters of the ordered non- $\mathrm{H}$ atoms were refined using an anisotropic approximation with the exception of disordered units. The hydrogen atoms of the amine ligands were located geometrically and refined using the riding model. The hydrogen atoms of the $\mu-\mathrm{H}_{3} \mathrm{O}_{2}$ ligand of the complex IV were located from residual electron density map. Crystallographic characteristics, experimental data, and the structure refinements are listed in Table S1. The structures of $\operatorname{trans}(\mathrm{NO}, \mathrm{F})-\operatorname{cis}\left(\mathrm{NH}_{3}, \mathrm{NH}_{3}\right)-\left[\mathrm{RuNO}\left(\mathrm{NH}_{3}\right)_{2}\left(\mathrm{H}_{2} \mathrm{O}\right)_{2} \mathrm{~F}\right] \mathrm{SiF}_{6}$ (I), $\operatorname{trans}(\mathrm{NO}, \mathrm{F})$ $\operatorname{cis}\left(\mathrm{NH}_{3}, \mathrm{NH}_{3}\right)-\left[\mathrm{RuNO}\left(\mathrm{NH}_{3}\right)_{2} \mathrm{Py}\left(\mathrm{NO}_{3}\right) \mathrm{F}\right]_{2} \mathrm{SiF}_{6} \cdot \mathrm{H}_{2} \mathrm{O}$ (II), trans $(\mathrm{NO}, \mathrm{F})-\operatorname{cis}\left(\mathrm{NH}_{3}, \mathrm{NH}_{3}\right)-\left[\mathrm{RuNO}\left(\mathrm{NH}_{3}\right)_{2} \mathrm{Py}\left(\mathrm{H}_{2} \mathrm{O}\right) \mathrm{F}\right]\left(\mathrm{ClO}_{4}\right)_{2}$ (III) and trans(NO,F)-cis $\left.\left(\mathrm{NH}_{3}, \mathrm{NH}_{3}\right)-\left[\left(\mathrm{RuNOPy}\left(\mathrm{NH}_{3}\right)_{2} \mathrm{~F}\right)_{2}\left(\mu-\mathrm{O}_{2} \mathrm{H}_{3}\right)\right](\mathrm{ClO})_{4}\right)_{3}(\mathrm{IV})$ have been deposited with the CCDC with refcodes 2050085, 2050086, 2050087 and 2050088 respectively.

\section{Hirshfeld surface analysis}

The Hirshfeld surfaces were calculated using Crystal Explorer ${ }^{38,39}$. This program allows the normalized contact distance $d_{\text {norm }}$ to be mapped onto the generated Hirshfeld surface. It is customary to map $d_{\text {norm }}$ using a redwhite-blue scheme, where red denotes close intermolecular contacts (negative $d_{n o r m}$ ), blue denotes longer contacts (positive $d_{\text {norm}}$ ) and white denotes intermolecular contacts equal to the van der Waals radii of atoms in contact $\left(d_{n o r m}=0\right)$. It is possible to obtain two-dimensional plots (fingerprint plots) from the surfaces mapped with $d_{\text {norm }}$ values.

\section{${ }^{14} \mathrm{~N}-\mathrm{NMR}$ spectroscopy}


The ${ }^{14} \mathrm{~N}-\mathrm{NMR}$ spectra of the $0.1 \mathrm{M}$ solution of trans- $\left(\mathrm{NO}, \mathrm{NO}_{3}\right)-\operatorname{cis}-\left(\mathrm{NH}_{3}, \mathrm{NH}_{3}\right)-\left[\mathrm{RuNO}\left(\mathrm{NH}_{3}\right)_{2} \mathrm{Py}_{2}\left(\mathrm{NO}_{3}\right)\right]\left(\mathrm{NO}_{3}\right)_{2} \cdot \mathrm{H}_{2} \mathrm{O}$ were recorded on the Bruker MSL-400 spectrometer at the $28.9 \mathrm{MGz}$ at room temperature in $\mathrm{D}_{2} \mathrm{O}$ as a solvent. The $1 \mathrm{M} \mathrm{NaNO}_{3}$ solution was used as a standard to measure the chemical shifts.

\section{IR-spectroscopy}

IR-spectroscopy measurements with irradiation were performed using a VERTEX 80v spectrometer with a resolution of $2 \mathrm{~cm}^{-1}$ in the range $400-4000 \mathrm{~cm}^{-1}$. The sample was ground, mixed with $\mathrm{KBr}$ and pressed into pellets. The $\mathrm{KBr}$ pellets were bonded onto the cold finger of a closed-cycle cryostat and irradiated by a 405, 445, 650 or $980 \mathrm{~nm}, 200 \mathrm{~mW}$ LED through $\mathrm{KBr}$ windows.

\section{Differential scanning calorimetry}

Differential scanning calorimeter NETZSCH DSC 204 F1 Phoenix was used to study kinetics and thermal effects accompanying the reverse MS1 $\rightarrow$ GS and MS2 $\rightarrow$ GS processes. DSC measurements of 1-3 mg powdered samples were performed in open aluminum crucibles by the heat flow measurement method at heating rate $9 \mathrm{~K} \mathrm{~min}^{-1}$ in $25 \mathrm{ml} / \mathrm{min}$ Ar flow. In order to increase the accuracy, measurements were carried out without a supply of gas/liquid nitrogen into the measurement cell during the experiment. The calibration of the sample carrier sensors and temperature scale graduation were performed by melting and crystal-to-crystal transition measurements of standard samples $\left(\mathrm{C}_{6} \mathrm{H}_{12}, \mathrm{Hg}, \mathrm{KNO}_{3}, \mathrm{In}\right)$. For the MS1 generation, irradiation of GS was performed at $80 \mathrm{~K}$ for $15 \mathrm{~min}$, using LED light at 405 or $445 \mathrm{~nm}$ with a light intensity of $200 \mathrm{~mW}$. The MS2 generation was made by the subsequent irradiation of the MS1 at $980 \mathrm{~nm} 200 \mathrm{~mW}$. Processing of the experimental data was performed with Netzsch Proteus Analysis software.

\section{Results and discussion}

\section{Reactivity and crystal structure analysis}

The reaction of fac- $\left[\mathrm{RuNO}\left(\mathrm{NH}_{3}\right)_{2}\left(\mathrm{NO}_{3}\right)_{3}\right]$ with hydrofluoric acid expectedly results in the full elimination of weakly bonded nitrate ligands from the inner coordination sphere of the ruthenium complex:

$$
\left[\mathrm{RuNO}\left(\mathrm{NH}_{3}\right)_{2}\left(\mathrm{NO}_{3}\right)_{3}\right]+\mathrm{HF}+2 \mathrm{H}_{2} \mathrm{O} \rightarrow\left[\mathrm{RuNO}\left(\mathrm{NH}_{3}\right)_{2}\left(\mathrm{H}_{2} \mathrm{O}\right)_{2} \mathrm{~F}\right]^{2+}+3 \mathrm{NO}_{3}{ }^{-}+\mathrm{H}^{+} .
$$

Earlier it was shown that a similar reaction with strong hydrochloric acid results in the complete substitution of nitrate ions to chloride ones ${ }^{35}$. The equilibrium concentration of fluoride ions in concentrated hydrofluoric acid is much lower compared to the concentration of chloride ions in hydrochloric acid, which results in partial aquation of the ligands in cis-positions to NO group. Following treatment of the reaction mixture with $\mathrm{SiF}_{6}{ }^{2-}$ leads to the precipitation of the trans $(\mathrm{NO}, \mathrm{F})-\operatorname{cis}\left(\mathrm{NH}_{3}, \mathrm{NH}_{3}\right)-\left[\mathrm{RuNO}\left(\mathrm{NH}_{3}\right)_{2}\left(\mathrm{H}_{2} \mathrm{O}\right)_{2} \mathrm{~F}\right] \mathrm{SiF}_{6}$ salt.

The structure of the trans $(\mathrm{NO}, \mathrm{F})-\operatorname{cis}\left(\mathrm{NH}_{3}, \mathrm{NH}_{3}\right)-\left[\mathrm{RuNO}\left(\mathrm{NH}_{3}\right)_{2}\left(\mathrm{H}_{2} \mathrm{O}\right)_{2} \mathrm{~F}\right] \mathrm{SiF}_{6}$ (I) is formed by the cationic ruthenium and anionic hexafluorosilicate octahedra. In the ruthenium complex ammine ligands are in cis- 
position to each other as well as $\mathrm{H}_{2} \mathrm{O}$ molecules. The nitrosyl ligand and fluoride one are in trans-position (see Fig. 1). Chosen bond distances and angles are shown in Table 1. The Ru-NO bond length equals $1.741(3) \AA$, which is characteristic for $\left\{\mathrm{Ru}^{2+}-\mathrm{NO}^{+}\right\}$species ${ }^{40}$. The intermolecular interactions are mostly represented by the $\mathrm{O}-\mathrm{H} \cdots \mathrm{F}$ and $\mathrm{N}-\mathrm{H} \cdots \mathrm{F}$ contacts, which are formed by the water and ammine ligands with fluoride atoms of the $\mathrm{SiF}_{6}{ }^{2-}$ anion. Each water ligand forms two strong hydrogen bonds with $\mathrm{F} 5$ and $\mathrm{F} 2$ atoms of $\mathrm{SiF}_{6}{ }^{2-}$ with $\mathrm{H} \cdots \mathrm{F}$ bond lengths of $1.906 \AA$ and $1.835 \AA$ r respectively. The ammine ligands form short contacts as well with $\mathrm{H} \cdots \mathrm{F}$ bond lengths equal

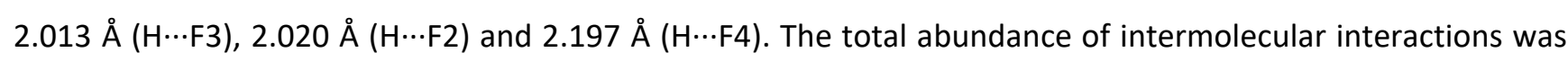
analyzed using Hirshfeld surfaces 38,39. The Hirshfeld surface of the $\operatorname{trans}(\mathrm{NO}, \mathrm{F})-\operatorname{cis}\left(\mathrm{NH}_{3}, \mathrm{NH}_{3}\right)$ $\left[\mathrm{RuNO}\left(\mathrm{NH}_{3}\right)_{2}\left(\mathrm{H}_{2} \mathrm{O}\right)_{2} \mathrm{~F}\right]^{2+}$ cation and corresponding two-dimensional fingerprints are shown in Fig. S1. According to the $2 \mathrm{D}$ fingerprints, the dominant intermolecular interactions are represented by the contacts of hydrogen atoms (66\%), from which the contacts $\mathrm{H} \cdots \mathrm{F}$ amount to $51 \%$. Importantly, the distances of the most predominant (frequent) $H \cdots F$ contacts vary in the range 1.9-2.3 $\AA$, which is in limit of the sum of van der Waals radii of $H$ and F atoms. The second prevailing interactions are formed by the oxygen atoms ( $22 \%$ of the total Hirshfeld surface).

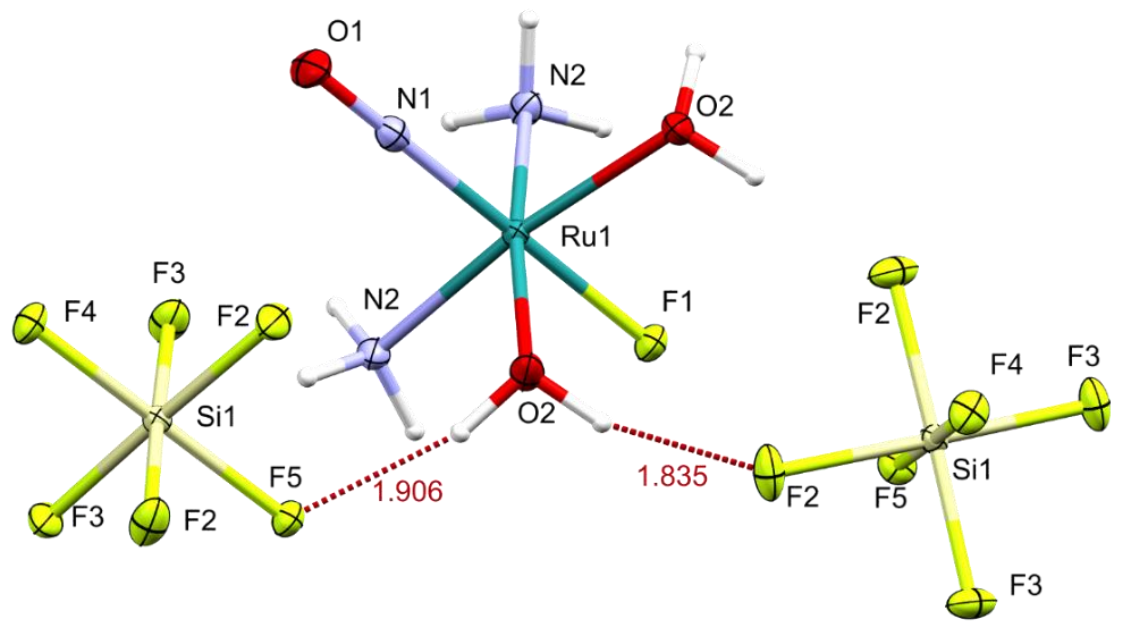

Fig. 1. The structure fragment of the complex $\operatorname{trans}(\mathrm{NO}, \mathrm{F})-\operatorname{cis}\left(\mathrm{NH}_{3}, \mathrm{NH}_{3}\right)-\left[\mathrm{RuNO}\left(\mathrm{NH}_{3}\right)_{2}\left(\mathrm{H}_{2} \mathrm{O}\right)_{2} \mathrm{~F}\right] \mathrm{SiF}_{6}(\mathrm{I})$ with chosen depicted intermolecular bond distances. Atomic displacement ellipsoids are given at the $50 \%$ probability level.

Table 1. The selected bond distances $[\AA \AA]$ and angles $\left[^{\circ}\right]$ in compounds I-III.

\begin{tabular}{|c|c|c|c|}
\hline Bond/angle & I & II & III \\
\hline $\mathrm{Ru}-\mathrm{NO}$ & $1.741(3)$ & $1.727(1)$ & $1.736(2)$ \\
\hline $\mathrm{N}-\mathrm{O}$ & $1.139(4)$ & $1.146(2)$ & $1.143(3)$ \\
\hline $\mathrm{Ru}-\mathrm{F}$ & $1.916(2)$ & $1.945(1)$ & $1.993(2)$ \\
\hline $\mathrm{Ru}-\mathrm{NH}_{3}$ & $2.054(2)$ & $2.090(2) ; 2.071(2)$ & $2.094(2) ; 2.071(3)$ \\
\hline $\mathrm{Ru}-\mathrm{Py}$ & - & $2.098(2)$ & $2.085(2)$ \\
\hline $\mathrm{Ru}-\mathrm{OH}_{2}$ & $2.098(2)$ & - & $2.071(3)$ \\
\hline $\mathrm{Ru}-\mathrm{ONO}_{2}$ & - & $2.068(2)$ & - \\
\hline $\mathrm{Ru}-\mathrm{N}-\mathrm{O}$ & $179.6(3)$ & $176.1(1)$ & $179.3(2)$ \\
\hline $\mathrm{ON}-\mathrm{Ru}-\mathrm{NH}_{3}$ & $93.2(1)$ & $91.9(1) ; 92.6(1)$ & $95.2(1) ; 93.9(1)$ \\
\hline $\mathrm{ON}-\mathrm{Ru}-\mathrm{Py}$ & - & $96.2(1)$ & $93.1(1)$ \\
\hline $\mathrm{ON}-\mathrm{Ru}-\mathrm{OH}_{2}$ & $93.4(1)$ & - & $95.3(1)$ \\
\hline $\mathrm{ON}-\mathrm{Ru}-\mathrm{ONO}_{2}$ & - & $99.2(1)$ & - \\
\hline
\end{tabular}


Two different cations trans(NO,F)-cis $\left(\mathrm{NH}_{3}, \mathrm{NH}_{3}\right)-\left[\mathrm{RuNO}\left(\mathrm{NH}_{3}\right)_{2}(\mathrm{Py})\left(\mathrm{H}_{2} \mathrm{O}\right) \mathrm{F}\right]^{2+}$ and $\operatorname{trans}(\mathrm{NO}, \mathrm{F})-\mathrm{cis}\left(\mathrm{NH}_{3}, \mathrm{NH}_{3}\right)-$ $\left[\mathrm{RuNO}\left(\mathrm{NH}_{3}\right)_{2}(\mathrm{Py})\left(\mathrm{NO}_{3}\right) \mathrm{F}\right]^{+}$were produced in the reaction of trans- $\left(\mathrm{NO}_{2} \mathrm{NO}_{3}\right)-\mathrm{cis}-\left(\mathrm{NH}_{3}, \mathrm{NH}_{3}\right)_{-}^{-}$ $\left[\mathrm{RuNO}\left(\mathrm{NH}_{3}\right)_{2} \mathrm{Py}_{2}\left(\mathrm{NO}_{3}\right)\right]\left(\mathrm{NO}_{3}\right)_{2} \cdot \mathrm{H}_{2} \mathrm{O}$ with HF:

$$
\begin{aligned}
& {\left[\mathrm{RuNO}\left(\mathrm{NH}_{3}\right)_{2}(\mathrm{Py})_{2}\left(\mathrm{NO}_{3}\right)\right]\left(\mathrm{NO}_{3}\right)_{2}+\mathrm{HF}+\mathrm{H}_{2} \mathrm{O} \rightarrow\left[\mathrm{RuNO}\left(\mathrm{NH}_{3}\right)_{2}(\mathrm{Py})\left(\mathrm{H}_{2} \mathrm{O}\right) \mathrm{F}\right]^{2+}+\mathrm{Py}+3 \mathrm{NO}_{3}{ }^{-}+\mathrm{H}^{+},} \\
& {\left[\mathrm{RuNO}\left(\mathrm{NH}_{3}\right)_{2}(\mathrm{Py})_{2}\left(\mathrm{NO}_{3}\right)\right]\left(\mathrm{NO}_{3}\right)_{2}+\mathrm{HF} \rightarrow\left[\mathrm{RuNO}\left(\mathrm{NH}_{3}\right)_{2}(\mathrm{Py})\left(\mathrm{NO}_{3}\right) \mathrm{F}\right]^{+}+\mathrm{Py}+2 \mathrm{NO}_{3}{ }^{-}+\mathrm{H}^{+} .}
\end{aligned}
$$

The first cation can be precipitated as a perchlorate salt $\operatorname{trans}(\mathrm{NO}, \mathrm{F})-\operatorname{cis}\left(\mathrm{NH}_{3}, \mathrm{NH}_{3}\right)$ $\left[\operatorname{RuNO}\left(\mathrm{NH}_{3}\right)_{2}(\mathrm{Py})\left(\mathrm{H}_{2} \mathrm{O}\right) \mathrm{F}\right]\left(\mathrm{ClO}_{4}\right)_{2}$ (III), the latter as a hexafluorosilicate trans $(\mathrm{NO}, \mathrm{F})-\mathrm{cis}\left(\mathrm{NH}_{3}, \mathrm{NH}_{3}\right)$ [RuNO $\left(\mathrm{NH}_{3}\right)_{2}(\mathrm{Py})\left(\mathrm{NO}_{3}\right) \mathrm{F}_{2}\left(\mathrm{SiF}_{6}\right) \cdot \mathrm{H}_{2} \mathrm{O}$ (II). In both cases the substitution of trans-to-NO nitrate-ligand is accompanied by partial substitution of the pyridine ligand. To have an idea of the kinetics of the pyridine ligand substitution during the reaction of trans- $\left(\mathrm{NO}, \mathrm{NO}_{3}\right)$-cis- $\left(\mathrm{NH}_{3}, \mathrm{NH}_{3}\right)-\left[\mathrm{RuNO}\left(\mathrm{NH}_{3}\right)_{2} \mathrm{Py}_{2}\left(\mathrm{NO}_{3}\right)\right]\left(\mathrm{NO}_{3}\right)_{2}$ with $\mathrm{HF}$, we performed a qualitative evaluation of the reaction kinetics in water solution by ${ }^{14} \mathrm{~N}-\mathrm{NMR}$. The partial aquation of the pyridine in cis-to-NO position in the starting trans- $\left(\mathrm{NO}, \mathrm{NO}_{3}\right)$-cis- $\left(\mathrm{NH}_{3}, \mathrm{NH}_{3}\right)-\left[\mathrm{RuNO}\left(\mathrm{NH}_{3}\right)_{2} \mathrm{Py}_{2}\left(\mathrm{NO}_{3}\right)\right]^{2+}$ occurs slowly at room temperature. Heating of the reaction mixture up to $85^{\circ} \mathrm{C}$ leads to an increase of the reaction conversion (see Figs S2 and S3). According to ${ }^{14} \mathrm{~N}-\mathrm{NMR}$ spectra, after 10 days at room temperature a weak additional signal at $-174.6 \mathrm{ppm}$ is already visible and should be assigned to the free pyridine due to the lower FWHM (full width at half maximum) value compared to one for the coordinated pyridine (peak at -156.9 ppm). After 4 hours of heating at $85^{\circ} \mathrm{C}$ the picture becomes more pronounced and a new shoulder arises in the range of the $\mathrm{NH}_{3}$ signal (-399.4 and $\left.-400.6 \mathrm{ppm}\right)$, which can be assigned to different trans- $\mathrm{NH}_{3}-\mathrm{Ru}-\mathrm{X}$ coordinate, illustrating an aquation of the initial complex and the formation of $\operatorname{trans}(\mathrm{NO}, \mathrm{F})-\operatorname{cis}\left(\mathrm{NH}_{3}, \mathrm{NH}_{3}\right)$ $\left[\mathrm{RuNO}\left(\mathrm{NH}_{3}\right)_{2}(\mathrm{Py})\left(\mathrm{H}_{2} \mathrm{O}\right) \mathrm{F}\right]^{2+}$ cation during reaction with $\mathrm{HF}$. The second product trans $(\mathrm{NO}, \mathrm{F})-\mathrm{cis}\left(\mathrm{NH}_{3}, \mathrm{NH}_{3}\right)^{-}$ $\left[\mathrm{RuNO}\left(\mathrm{NH}_{3}\right)_{2}(\mathrm{Py})\left(\mathrm{NO}_{3}\right) \mathrm{F}\right]^{+}$is more interesting and its formation can be explained only by the outer-to-inner exchange of the nitrate-anion. Similar reactions are well known for such ligands as $\mathrm{Cl}^{-41}$. Taking into account the difference in the charge of the produced cations, we can explain its separation with different anions by a difference in solubility of the resulted complexes.

The structure of the trans $(\mathrm{NO}, \mathrm{F})-\mathrm{cis}\left(\mathrm{NH}_{3}, \mathrm{NH}_{3}\right)-\left[\mathrm{RuNO}\left(\mathrm{NH}_{3}\right)_{2} \mathrm{Py}\left(\mathrm{NO}_{3}\right) \mathrm{F}\right]_{2} \mathrm{SiF}_{6} \cdot \mathrm{H}_{2} \mathrm{O}$ (II) comprises cationic ruthenium and anionic $\mathrm{SiF}_{6}{ }^{2-}$ parts similar to I and contains a captured solvate molecule of water (see Fig. 2). The ammine ligands are coordinated to ruthenium center in cis-position to each other, nitrosyl and fluoride ligands are in trans-position, similar to I. Pyridine and nitrate ligands are in cis-position. As can be seen from Table 1, there are peculiarities in the $\mathrm{Ru}-\mathrm{NH}_{3}$ bond lengths with respect to trans-ligands. Accordingly, the bond length Ru- $\mathrm{NH}_{3}$ is about $0.02 \AA$ larger when the Py is trans-ligand (2.090(2) $\AA$ ) compared to $\mathrm{NO}_{3}{ }^{-}$one $(2.071(2) \AA$ ), which is probably due to different ligand field of $\mathrm{Py}$ and $\mathrm{NO}_{3}$. The crystal packing is built by the hydrogen bonds of $\mathrm{NH}_{3}$

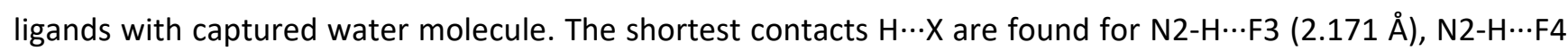

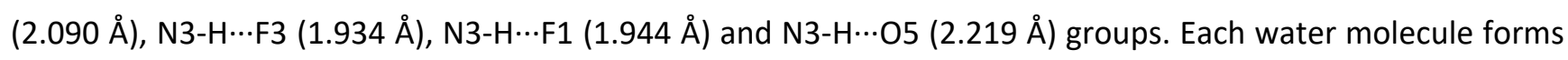


two hydrogen bonds $\mathrm{H} \cdots \mathrm{F}$ with F1 (2.020 $\AA$ ) and F2 (1.959 $\AA$ ) atoms. Similar to compound I, the biggest contribution to the whole intermolecular interactions is made by hydrogen atoms (57\%) (see Hirshfeld surface of the trans $(\mathrm{NO}, \mathrm{F})-\operatorname{cis}\left(\mathrm{NH}_{3}, \mathrm{NH}_{3}\right)-\left[\mathrm{RuNO}\left(\mathrm{NH}_{3}\right)_{2} \mathrm{Py}\left(\mathrm{NO}_{3}\right) \mathrm{F}\right]^{+}$cation in Fig. S4). However, unlike I the hydrogen contacts are less specific, and the contribution of $\mathrm{H} \cdots \mathrm{F}(16 \%), \mathrm{H} \cdots \mathrm{O}(19 \%)$ and $\mathrm{H} \cdots \mathrm{H}(19 \%)$ interactions is almost the same. Accordingly, 2D fingerprint plots reveal no overly frequent contacts, unlike complex I (absence of red areas on the fingerprint). Contacts formed by oxygen atoms occupy $27 \%$ of the whole Hirshfeld surface mostly by $\mathrm{O} \cdots \mathrm{H}$ contacts $(17 \%)$.

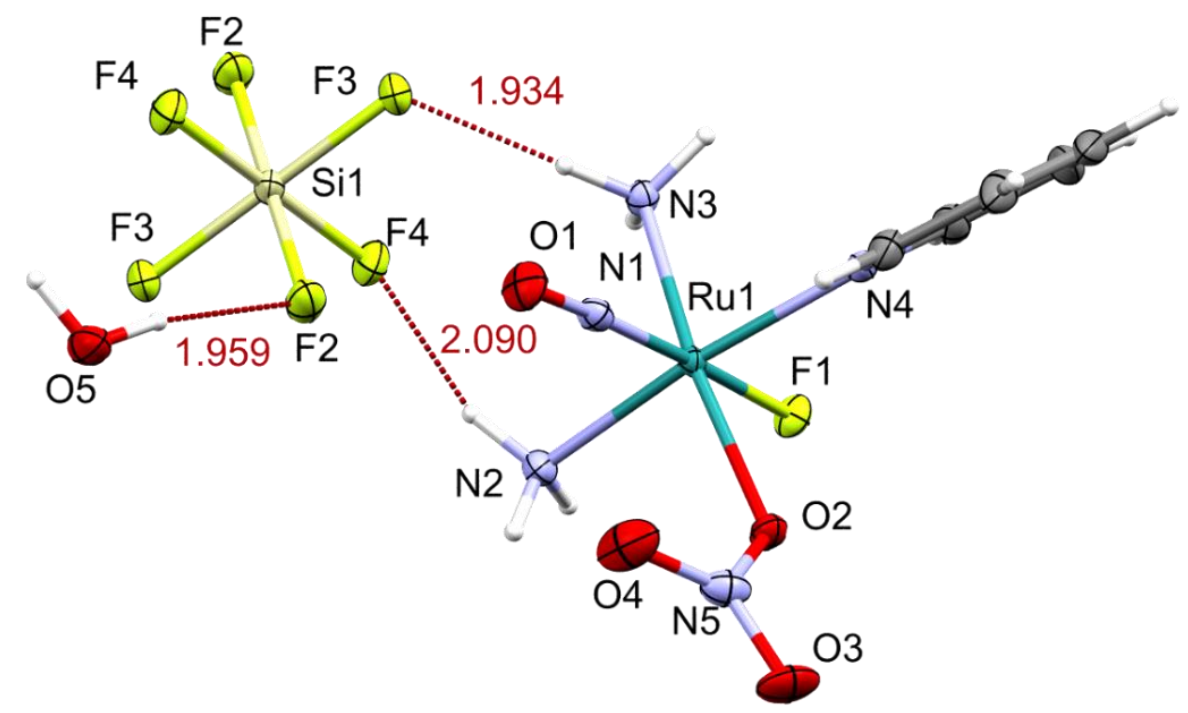

Fig. 2. The structure fragment of the complex trans(NO,F)-cis $\left(\mathrm{NH}_{3}, \mathrm{NH}_{3}\right)-\left[\mathrm{RuNO}\left(\mathrm{NH}_{3}\right)_{2} \mathrm{Py}\left(\mathrm{NO}_{3}\right) \mathrm{F}\right]_{2} \mathrm{SiF}_{6} \cdot \mathrm{H}_{2} \mathrm{O}(\mathrm{II})$ with chosen depicted intermolecular bond distances. Atomic displacement ellipsoids are given at the $50 \%$ probability level.

The structure of trans $\left.(\mathrm{NO}, \mathrm{F})-\operatorname{cis}\left(\mathrm{NH}_{3}, \mathrm{NH}_{3}\right)-\left[\mathrm{RuNO}\left(\mathrm{NH}_{3}\right)_{2} \mathrm{Py}\left(\mathrm{H}_{2} \mathrm{O}\right) \mathrm{F}\right](\mathrm{ClO})_{4}\right)_{2}$ (III) resembles the structure of II, except for an anion $\left(\mathrm{ClO}_{4}{ }^{-}\right)$and a water ligand instead of nitrate (see Fig. 3). The feature of different $\mathrm{Ru}-\mathrm{NH}_{3}$ bond lengths depending on the trans-to- $\mathrm{NH}_{3}$ ligand is present as well. The $\mathrm{Ru}-\mathrm{NH}_{3}$ bond length with pyridine in transposition is longer (2.094(2) $\AA$ ) compared to that for aqua ligand (2.071(3) $\AA$ ) (see Table 1). There is significant difference in Ru-F bond lengths of the complexes I-III. For instance, the Ru-F bond length in III is longer by 0.077 $\AA$ than that for I. Presumably, this is due to the very short hydrogen bond $\mathrm{O} 2-\mathrm{H} \cdots \mathrm{F} 1$ between aqua and fluoride ligand in the complex III. The ammine ligands also form hydrogen bonds with oxygen atoms of perchlorate

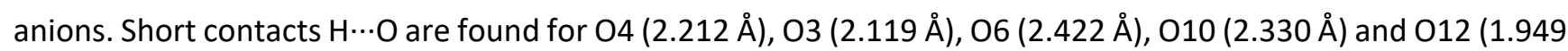
Å) atoms. From the Hirshfeld surface analysis point of view, intermolecular interactions in the structure of III are mostly represented by contacts of hydrogen atoms (70\%), with dominating contacts $\mathrm{H} \cdots \mathrm{O}(48 \%)$ (see Hirshfeld surface of the trans(NO,F)-cis $\left(\mathrm{NH}_{3}, \mathrm{NH}_{3}\right)-\left[\mathrm{RuNO}\left(\mathrm{NH}_{3}\right)_{2} \mathrm{Py}\left(\mathrm{H}_{2} \mathrm{O}\right) \mathrm{F}\right]^{2+}$ cation in Fig. S5). Similar to the compound II, no overly frequent contacts are found in a $2 \mathrm{D}$ fingerprint. The interactions formed by oxygen and carbon atoms occupy $12 \%$ and $10 \%$ of the surface respectively. 


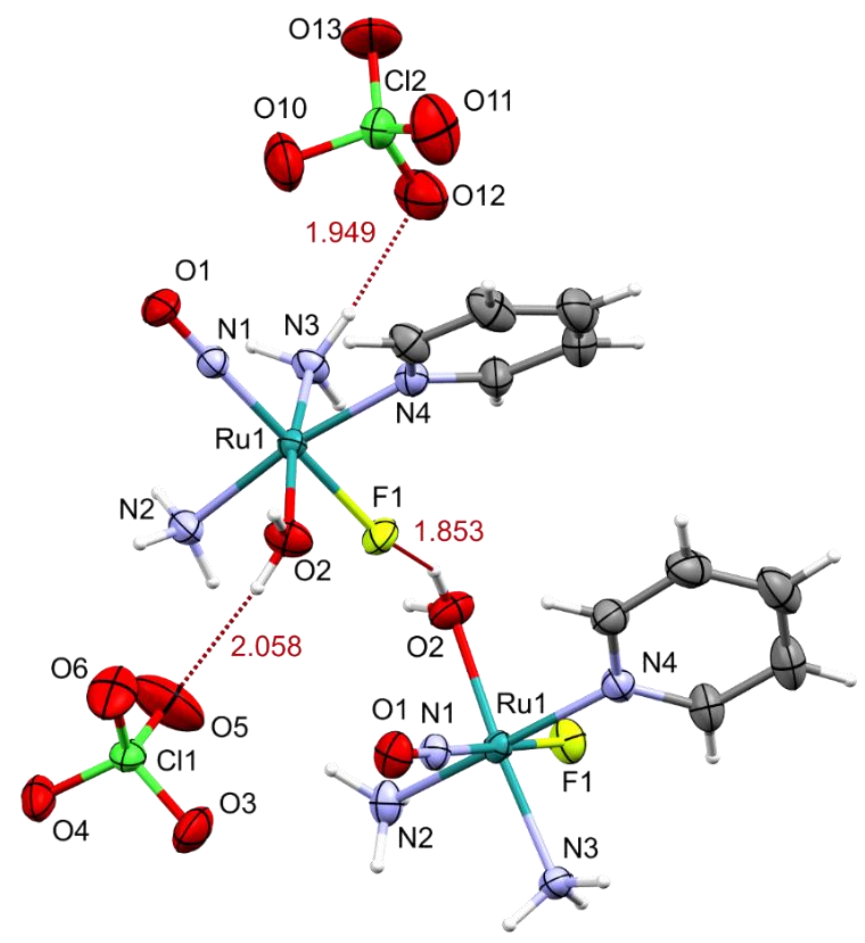

Fig. 3. The structure fragment of the complex trans(NO,F)-cis $\left(\mathrm{NH}_{3}, \mathrm{NH}_{3}\right)-\left[\mathrm{RuNO}\left(\mathrm{NH}_{3}\right)_{2} \mathrm{Py}\left(\mathrm{H}_{2} \mathrm{O}\right) \mathrm{F}\right]\left(\mathrm{ClO}_{4}\right)_{2}(\mathrm{III})$ with chosen depicted intermolecular bond distances. Atomic displacement ellipsoids are given at the 50\% probability level.

Ruthenium complexes containing $\mu-\mathrm{H}_{3} \mathrm{O}_{2}{ }^{-}$bridge ligand are extremely rare. According to the Cambridge Structural Database (CSD) there is only five known complexes with $\mu-\mathrm{H}_{3} \mathrm{O}_{2}{ }^{-}:\left[\{\mathrm{Ru}(\mathrm{acac})\}_{2}\left(\mu-\mathrm{O}_{2} \mathrm{H}_{3}\right)\right]\left(\mathrm{PF}_{6}\right)_{3}{ }^{42}$, sevencoordinated $\mu-\mathrm{O}_{2} \mathrm{H}_{3}\left[\mathrm{RuL}(\text { pic })_{2}\right]_{2}\left(\mathrm{PF}_{6}\right)_{3} \cdot 2 \mathrm{H}_{2} \mathrm{O}{ }^{43}, \quad\left[\left\{L^{\prime} \mathrm{Ru}(\text { bqdi) }\}_{2}\left(\mu-\mathrm{O}_{2} \mathrm{H}_{3}\right)\right]\left(\mathrm{PF}_{6}\right)_{3}{ }^{44}, \quad\left[\left\{\mathrm{Ru}(\mathrm{NO})(\mathrm{pyca})_{2}\right\}_{2}(\mu-\right.\right.$ $\left.\left.\mathrm{H}_{3} \mathrm{O}_{2}\right)\right] \mathrm{PF}_{6} \cdot 2 \mathrm{H}_{2} \mathrm{O}{ }^{45}$ and $\left\{[\mathrm{Ru}(\operatorname{trpy})]_{2}(\mu-\mathrm{bpp})\left(\mu-\mathrm{O}_{2} \mathrm{H}_{3}\right)\right\}\left(\mathrm{PF}_{6}\right)_{2}{ }^{46}$ and cis- $\left\{\left[\mathrm{Ru}(\mathrm{NO})\left(\mathrm{NH}_{3}\right)_{2} \mathrm{Cl}_{2}\left(\mu_{2}-\mathrm{H}_{3} \mathrm{O}_{2}\right)\right\} \mathrm{Cl}^{58}\right.$. In the listed complexes a formation of strong hydrogen bond $(\mathrm{O} \cdots \mathrm{O}$ distance is about $\approx 2.4 \AA$ ) is responsible for a formation of the dimeric structures. Concerning the $\left.\operatorname{trans}(\mathrm{NO}, \mathrm{F})-\operatorname{cis}\left(\mathrm{NH}_{3}, \mathrm{NH}_{3}\right)-\left[\left(\mathrm{RuNOPy}\left(\mathrm{NH}_{3}\right)_{2} \mathrm{~F}\right)_{2}\left(\mu-\mathrm{O}_{2} \mathrm{H}_{3}\right)\right](\mathrm{ClO})_{3}\right)_{3}$ (IV) complex, a motif of ruthenium octahedron is the same as for compound III. Apparently, there is an equilibrium between monomeric III and dimeric IV forms of the complex. Depending on crystallization conditions one or another form prevails. In the complex IV, bond lengths of two ruthenium units are similar (see Table 2). The $\mathrm{O} \cdots \mathrm{O}$ bond length in the $\mu-\mathrm{H}_{3} \mathrm{O}_{2}{ }^{-}$bridge ligand is $2.403(3) \AA$ with $\mathrm{O}-\mathrm{H}-\mathrm{O}$ angle of $173(5)^{\circ}$. Each oxygen atom of the $\mu-\mathrm{H}_{3} \mathrm{O}_{2}^{-}$forms quite short hydrogen bonds with oxygen atoms of $\mathrm{ClO}_{4}^{-}$. The $\mathrm{H} \cdots \mathrm{O}$ bond distances in $\mathrm{O} 22-$ $\mathrm{H} \cdots \mathrm{O} 34$ and $\mathrm{O} 21-\mathrm{H} \cdots \mathrm{O} 35$ are $2.095 \AA$ and $1.975 \AA$ respectively. The ammine ligands as well form contacts $\mathrm{N}$ $\mathrm{H} \cdots \mathrm{O}$ with average $\mathrm{H} \cdots \mathrm{O}$ distance of $2.28 \AA$. The Hirshfeld surface of the $\operatorname{trans}(\mathrm{NO}, \mathrm{F})-\operatorname{cis}\left(\mathrm{NH}_{3}, \mathrm{NH}_{3}\right)-$ $\left[\left(\mathrm{RuNOPy}\left(\mathrm{NH}_{3}\right)_{2} \mathrm{~F}\right)_{2}\left(\mu-\mathrm{O}_{2} \mathrm{H}_{3}\right)\right]^{3+}$ cation is shown in Fig. S6. According to the surfaces and 2D fingerplots, diversity and dominance of types of the intermolecular contacts are similar to the complex III. The intermolecular interactions are mostly represented by contacts of hydrogen atoms (72\%), where $\mathrm{H} \cdots \mathrm{O}$ interactions occupy $44 \%$. The remaining interactions are represented by oxygen (11\%) and carbon (10\%) atoms. 


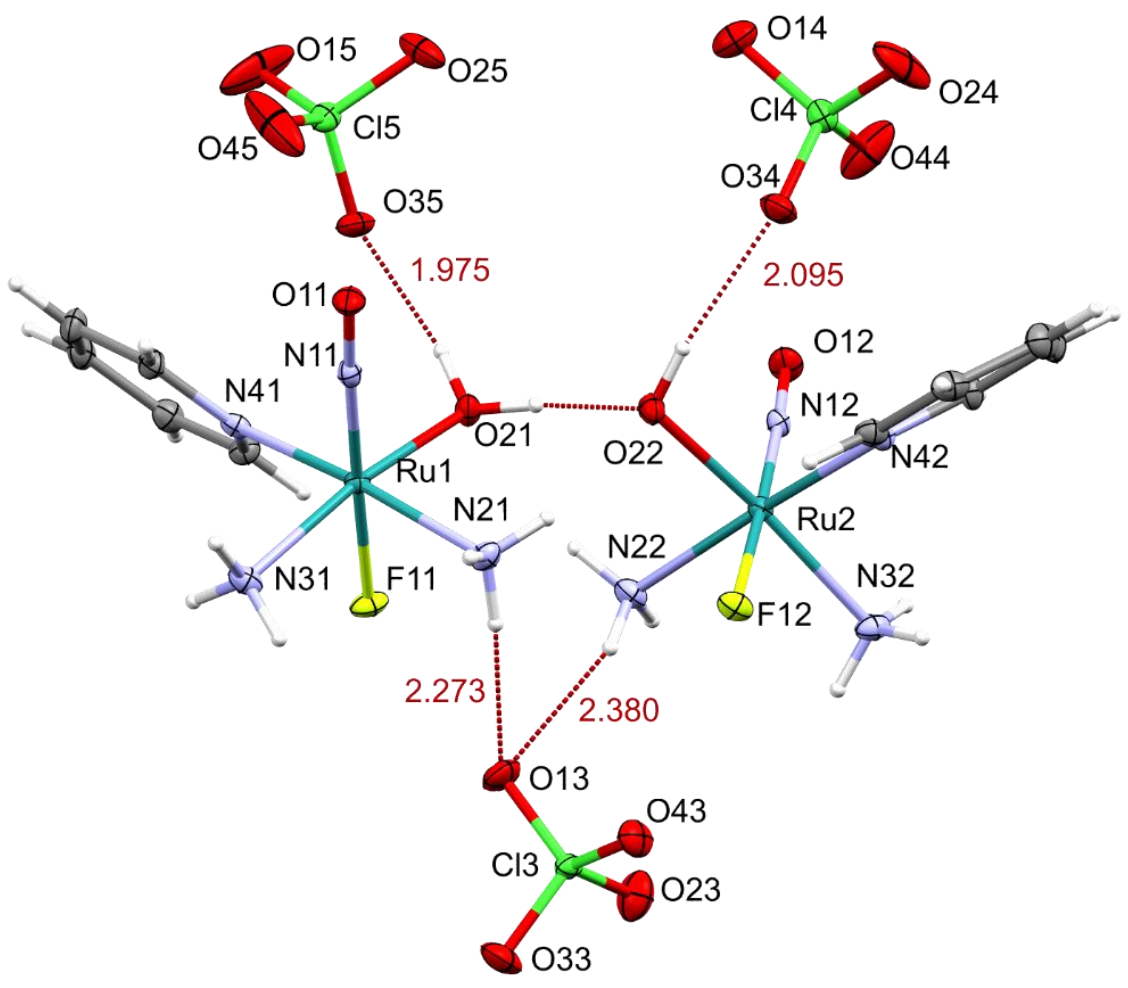

Fig. 4. The structure fragment of the complex $\left.\operatorname{trans}(\mathrm{NO}, \mathrm{F})-\operatorname{cis}\left(\mathrm{NH}_{3}, \mathrm{NH}_{3}\right)-\left[\left(\mathrm{RuNOPy}\left(\mathrm{NH}_{3}\right)_{2} \mathrm{~F}\right)_{2}\left(\mu-\mathrm{O}_{2} \mathrm{H}_{3}\right)\right](\mathrm{ClO})_{4}\right)_{3}$ (IV) with chosen depicted intermolecular bond distances. Atomic displacement ellipsoids are given at the $50 \%$ probability level.

Table 2. The selected bond distances $[\AA]$ and angles $\left[^{\circ}\right]$ in the $\operatorname{trans}(\mathrm{NO}, \mathrm{F})-\operatorname{cis}\left(\mathrm{NH}_{3}, \mathrm{NH}_{3}\right)$ $\left[\left(\operatorname{RuNOPy}\left(\mathrm{NH}_{3}\right)_{2} \mathrm{~F}\right)_{2}\left(\mu-\mathrm{O}_{2} \mathrm{H}_{3}\right)\right]$ (IV).

\begin{tabular}{|c|c|c|}
\hline Bond/angle & Ru1 unit & Ru2 unit \\
\hline $\mathrm{Ru}-\mathrm{NO}$ & $1.737(2)$ & $1.735(2)$ \\
\hline $\mathrm{N}-\mathrm{O}$ & $1.152(3)$ & $1.151(3)$ \\
\hline $\mathrm{Ru}-\mathrm{NH}_{3}$ & $2.112(2) ; 2.090(3)$ & $2.111(2) ; 2.098(3)$ \\
\hline $\mathrm{Ru}-\mathrm{Py}$ & $2.092(2)$ & $2.078(2)$ \\
\hline $\mathrm{Ru}-\mathrm{F}$ & $1.909(2)$ & $1.919(2)$ \\
\hline $\mathrm{Ru}-\mathrm{OH}$ & $2.042(2)$ & $2.042(2)$ \\
\hline $\mathrm{Ru}-\mathrm{N}-\mathrm{O}$ & $177.4(2)$ & $177.2(2)$ \\
\hline $\mathrm{ON}-\mathrm{Ru}-\mathrm{NH}_{3}$ & $93.1(1)$ & $93.3(1)$ \\
\hline $\mathrm{ON}-\mathrm{Ru}-\mathrm{NH}_{3}$ & $96.1(1)$ & $96.2(1)$ \\
\hline $\mathrm{ON}-\mathrm{Ru}-\mathrm{Py}$ & $95.7(1)$ & $94.5(1)$ \\
\hline $\mathrm{ON}-\mathrm{Ru}-\mathrm{OH}_{2}$ & $95.1(1)$ & $94.3(1)$ \\
\hline
\end{tabular}

From the overall analysis of the four crystal structures, we can highlight the following: the Ru-NO bond lengths vary in range 1.727(1) - 1.741(3) $\AA$ with almost linear Ru-N-O angle; the intramolecular bond lengths in ruthenium octahedron depend on different trans-ligands (namely the $\mathrm{Ru}-\mathrm{NH}_{3}$ bonds are affected) as well as on different involvement of ligands in intermolecular interactions (difference in the Ru-F bond lengths, which vary in range 1.909(2) - 1.993(2) Å); the crystal packing is formed mostly by contacts of hydrogen atoms (about 60 - 
$70 \%$ of total Hirshfeld surface), where intermolecular interactions are represented by reasonably short hydrogen bonds $\mathrm{H} \cdots \mathrm{F} / \mathrm{O}$.

\section{Photoinduced nitrosyl ligand isomerization}

The formation of linkage isomers MS1 and MS2 after light exposure of the GS in the complexes I, II and III is studied by the low temperature ( $80 \mathrm{~K}$ ) IR-spectroscopy. The wavenumbers of the V(NO) bands of the GS of I, II and III are shown in Table 3. The blue light ( 405 or $445 \mathrm{~nm}$ ) irradiation of the GS induces the formation of new bands in spectra assigned to the MS1 isomers (see Fig. 5, panels a). New bands of v(NO) appear at 1778, 1801 and $1784 \mathrm{~cm}^{-1}$ for I, II and II respectively. The shift of the bands are about $130 \mathrm{~cm}^{-1}$ to lower energy from positions of the GS, which is common for ruthenium nitrosyl complexes ${ }^{2,21,22}$. Populations of the MS1 were calculated from a decrease of the area under $v(N O)$ band of the GS $\left(\% M S 1=100-\left(I\left(v(N O)_{G S}\right.\right.\right.$ after $) / I\left(v(N O)_{G S}\right.$ before $\left.\left.)\right) \cdot 100\right)$ and are shown in Table 3. The maximum achieved populations are found using light of wavelength $445 \mathrm{~nm}$ for I, and $405 \mathrm{~nm}$ for II and III. Besides of the formation of the v(NO) bands of the MS1, weak but distinguishable changes in $\delta\left(\mathrm{NH}_{3}\right), \mathrm{v}(\mathrm{Ru}-(\mathrm{NO})) / \delta(\mathrm{Ru}-\mathrm{N}-\mathrm{O})$ and $\mathrm{v}(\mathrm{Ru}-\mathrm{F})$ bands are observed. In I, the listed bands appear at $837 \mathrm{~cm}^{-1}(936$ and $906 \mathrm{~cm}^{-1}$ in GS), 580, 532 and $517 \mathrm{~cm}^{-1}\left(546,523\right.$ and $504 \mathrm{~cm}^{-1}$ in GS) and $438 \mathrm{~cm}^{-1}\left(457 \mathrm{~cm}^{-1}\right.$ in GS) respectively. In II and III, the only change is observed in the $\mathrm{v}(\mathrm{Ru}-(\mathrm{NO})) / \delta(\mathrm{Ru}-\mathrm{N}-\mathrm{O})$ modes $\left(575 \mathrm{~cm}^{-1}\right.$ (MS1) vs. $540 \mathrm{~cm}^{-1}$ (GS) in II, and $581 \mathrm{~cm}^{-1}$ (MS1) vs. $529 \mathrm{~cm}^{-1}$ (GS) in III). The subsequent irradiation of the MS1 by light of wavelength $980 \mathrm{~nm}$ induces an appearance of absorption at 1565,1587 and $1564 \mathrm{~cm}^{-1}$ for I, II and III respectively. The bands are assigned to the formation of MS2 isomers (see Fig. 5, panels b). Importantly, both MS1 and MS2 can be reversibly transferred to back to the GS by an exposure to red light, with wavelength $650 \mathrm{~nm}$.

From the determined populations of the MS1, the population is significantly increased from 7 to 26 percent from I to III. It is known that pyridine is an equatorial ligand leading to potentially high populations ${ }^{17,47}$. But in order to obtain high populations other parameters are involved, including appropriate absorption properties in the three states GS, MS1 and MS2 allowing for efficient transfer GS $\rightarrow$ MS2 $\rightarrow$ MS1, without corresponding backtransferring processes ${ }^{48,49}$. Also the counter ion can have a significant influence on the maximum achievable population, as has been shown by Cormary et al. on a series of trans-[RuNO(py $\left.)_{4} \mathrm{~L}\right]^{2+}\left(\mathrm{L}^{2}=\mathrm{Cl}^{-}, \mathrm{Br}^{-}\right)$compounds ${ }^{50}$ and on series of trans-[RuNO $\left.\left(\mathrm{NH}_{3}\right)_{4} \mathrm{~F}\right]^{2+}$ complexes ${ }^{21}$. The intermolecular contacts of the NO ligands are shown in Table S2. From the table, the shortest contacts are observed in the compound I, which contradict that shorter intermolecular contacts of NO increase the population of MS1 ${ }^{50}$. Another possible reason of the increase of the MS1 population is an increase of Ru-F bond length from I to III (see Table 1).

Table 3. The position of $\mathrm{v}(\mathrm{NO})$ bands $\left(\mathrm{cm}^{-1}\right)$ of GS, MS1, MS2 and maximum achieved population (\%) of MS1 and MS2 in complexes I, II and III.

\begin{tabular}{|c|c|c|c|c|c|}
\hline Complex & $\mathrm{GS}, \mathrm{cm}^{-1}$ & $\mathrm{MS} 1, \mathrm{~cm}^{-1}$ & $\mathrm{MS} 1, \%$ & $\mathrm{MS} 2, \mathrm{~cm}^{-1}$ & $\mathrm{MS} 2, \%$ \\
\hline I & 1914 & 1778 & 7 & 1565 & 1 \\
\hline II & 1933 & 1801 & 12 & 1587 & 5 \\
\hline III & 1923 & 1784 & 26 & 1564 & 6 \\
\hline
\end{tabular}



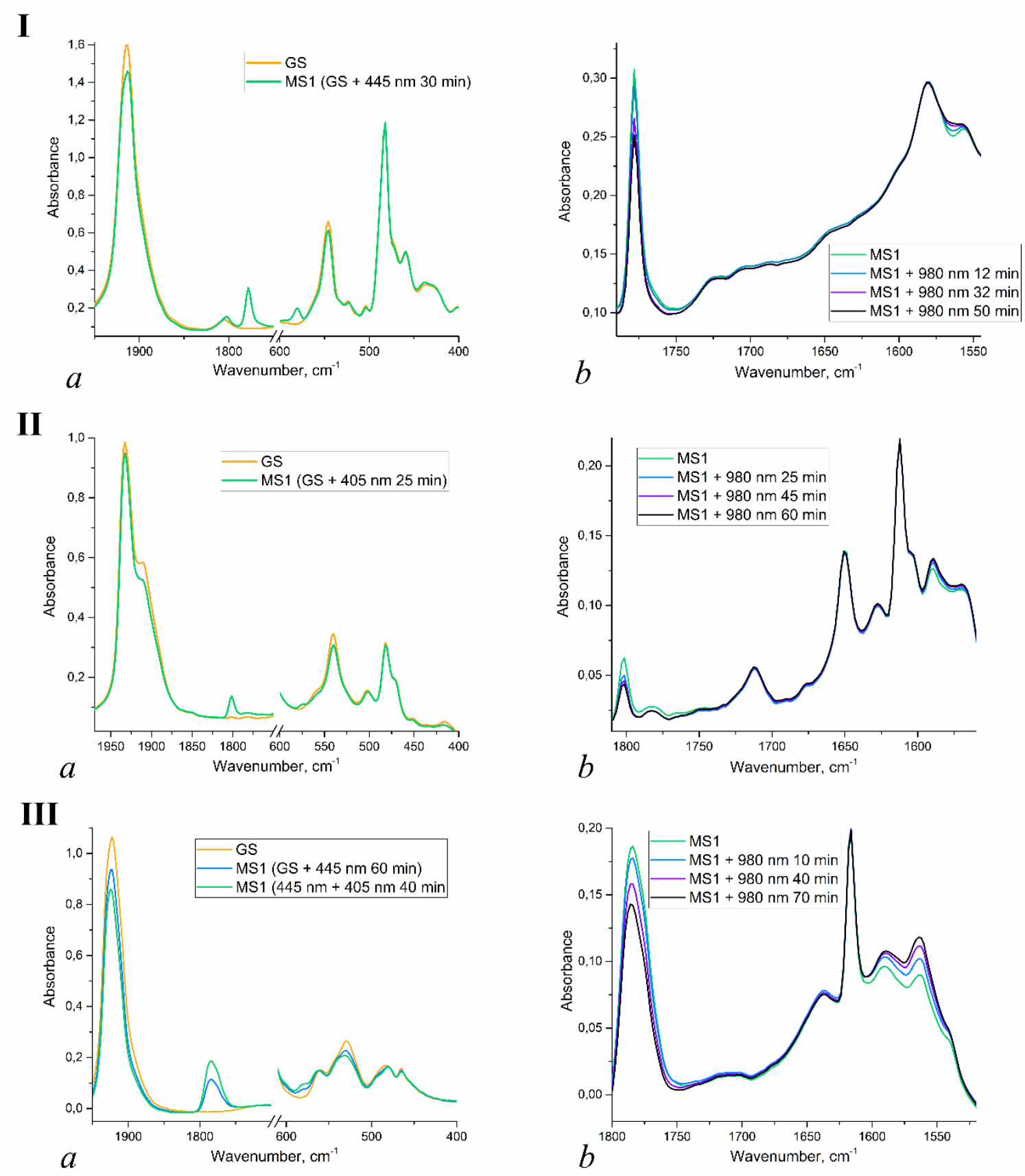

Fig. 5. Light-induced transformations in trans $(\mathrm{NO}, \mathrm{F})-\operatorname{cis}\left(\mathrm{NH}_{3}, \mathrm{NH}_{3}\right)-\left[\mathrm{RuNO}\left(\mathrm{NH}_{3}\right)_{2}\left(\mathrm{H}_{2} \mathrm{O}\right)_{2} \mathrm{~F}\right] \mathrm{SiF}_{6}(\mathrm{I})$, trans $(\mathrm{NO}, \mathrm{F})$ $\operatorname{cis}\left(\mathrm{NH}_{3}, \mathrm{NH}_{3}\right)-\left[\mathrm{RuNO}\left(\mathrm{NH}_{3}\right)_{2} \mathrm{Py}\left(\mathrm{NO}_{3}\right) \mathrm{F}\right]_{2} \mathrm{SiF}_{6} \cdot \mathrm{H}_{2} \mathrm{O}$ (II) and trans $(\mathrm{NO}, \mathrm{F})-\operatorname{cis}\left(\mathrm{NH}_{3}, \mathrm{NH}_{3}\right)-\left[\mathrm{RuNO}\left(\mathrm{NH}_{3}\right)_{2} \mathrm{Py}\left(\mathrm{H}_{2} \mathrm{O}\right) \mathrm{F}\right]\left(\mathrm{ClO}_{4}\right)_{2}$ (III) at $80 \mathrm{~K}$ by IR-spectroscopy. Panels $a$ represent changes of GS after 405/445 nm irradiation (MS1). Panels $b$ show the formation of MS2 after subsequent infrared $(980 \mathrm{~nm}$ ) exposure of MS1.

Since formation of MS1 from GS is presumably a two-stage process including absorption of two photons via GS $\rightarrow$ MS2 $\rightarrow$ MS1 consecutive reaction, there is certain restriction on the MS1 photogeneration at temperatures higher than $80 \mathrm{~K}^{22,51}$. The maximum temperatures, at which MS1 can be generated and detected $\left(T_{\max }\right)$ are 270 $\mathrm{K}$ (I, $10 \mathrm{~min}$ of $445 \mathrm{~nm}$ irradiation), $220 \mathrm{~K}$ (II, $10 \mathrm{~min}$ of $405 \mathrm{~nm}$ irradiation) and $260 \mathrm{~K}$ (III, $10 \mathrm{~min}$ of $405 \mathrm{~nm}$ 
irradiation) with MS1 populations of about $0.1 \%$. Such a significant difference in the temperatures $T_{\max }$ is related to the different lifetimes of the MS2 at these temperatures, which is discussed below.

The thermal decay kinetics of the metastable states is studied by Differential Scanning Calorimetry (DSC), since the reactions MS1/MS2 $\rightarrow$ GS are exothermic. The DSC curves obtained upon heating after generation of MS1 and MS2 at $80 \mathrm{~K}$ are shown in Fig. 6 . The curves are fitted by the first order kinetic equation $\mathrm{dH} / \mathrm{dt}=\mathrm{H}_{\text {tot }}$. $(1-\alpha) k_{0} \cdot \exp \left(-E_{a} /(R \cdot T)\right)$, where $d H / d t$ is the heat flow rate, $H_{\text {tot }}$ is the total reaction enthalpy, $\alpha$ is the conversion, $R$ is the universal gas constant and $T$ is the temperature. The calculated activation energies $\left(E_{a}\right)$ and frequency factors $\left(I \mathrm{gk}_{0}\right)$ of the transformations are listed in Table 4. In order to compare the thermal stability of the MS1 with that found for other compounds, decay temperatures $T_{d}$ are calculated at $k=10^{-3} \mathrm{~s}^{-1}$ using Arrhenius law and shown in Table $4^{19}$. All compounds show very high decay temperatures of MS1 (the highest decay temperature was found in the trans-[RuNO$\left.\left(\mathrm{NH}_{3}\right)_{4} \mathrm{~F}\right]\left[\mathrm{PdCl}_{4}\right]$, which equals $\left.307 \mathrm{~K}^{21}\right)$. The high MS1 thermal stability is due to electronegative fluoride ligand in trans-position to NO, which greatly increases the activation energy of the reaction MS1 $\rightarrow \mathrm{GS}^{20,23}$. As can be seen from Table 4, the decay temperatures of MS1 in II and III are higher with respect to that in I. The opposite behavior is observed concerning the thermal stability of MS2, for which $\mathrm{T}_{\mathrm{d}}$ of II is lower by $20 \mathrm{~K}$ compared to I and III (see Table 4). The different patterns of the MS1 and MS2 thermal stability could be attributed to the change of the ligand environment of ruthenium in the complexes. Also, this is an example of that increase or decrease of thermal stability of one linkage isomer does not predict corresponding increase or decrease of another. This can be understood, given the fact that the structural configuration of the nitrosyl ligand in MS1 and MS2 (Ru-ON vs. Ru- $\eta^{2}-(N O)$ ) is quite different and thus environmental effects might differ significantly ${ }^{22,47}$. To the best of our knowledge, the decay temperatures of MS2 in the I and III are the highest to date among complexes where thermal stability of MS1 is higher than that for MS2. The previously described complexes $\left[\mathrm{RuNO}\left(\mathrm{NH}_{3}\right)_{5}\right] \mathrm{Cl}_{3} \cdot \mathrm{H}_{2} \mathrm{O}$ and trans-[RuNO$\left.\left(\mathrm{NH}_{3}\right)_{4}\left(\mathrm{H}_{2} \mathrm{O}\right)\right] \mathrm{Cl} \mathrm{l}_{3} \cdot \mathrm{H}_{2} \mathrm{O}$ possess $T_{d}$ of MS2 of $212^{52}$ and $211 \mathrm{~K}^{53}$ respectively. Interestingly, in the cyanide complexes of ruthenium $\left(\mathrm{Na}_{2}\left[\mathrm{RuNO}(\mathrm{CN})_{5}\right] \cdot 2 \mathrm{H}_{2} \mathrm{O}\right){ }^{54}$ and osmium $\left(\mathrm{Na}_{2}\left[\mathrm{OsNO}(\mathrm{CN})_{5}\right] \cdot 2 \mathrm{H}_{2} \mathrm{O}\right){ }^{55}$ the reverse behavior of thermal stability of metastable states was shown, i.e. the $T_{d}$ of MS2 is higher than the $T_{d}$ of MS1. In these studies, the kinetic parameters of the thermal decay of metastable states were not determined, however decay temperatures of MS2 can be roughly estimated to 220 and $240 \mathrm{~K}$ for osmium and ruthenium complexes respectively.

Table 4. Kinetic parameters (activation energy $\left(E_{a}\right)$, frequency factor $\left(\operatorname{lgk}_{0}\right)$ and decay temperature $\left.\left(T_{d}\right)\right)$ of the MS1 $\rightarrow \mathrm{GS}$ and MS2 $\rightarrow \mathrm{GS}$ transformations determined by DSC.

\begin{tabular}{|c|c|c|c|c|}
\hline Complex & Decay & $\mathrm{E}_{\mathrm{a}}, \mathrm{kJ} \mathrm{mol}^{-1}$ & $\mathrm{Igk}_{0}$ & $\mathrm{~T}_{\mathrm{d}}, \mathrm{K}$ \\
\hline \multirow{2}{*}{$\mathrm{I}$} & $\mathrm{MS} 1$ & $107.5 \pm 2.9$ & $16.8 \pm 0.5$ & 284 \\
\cline { 2 - 5 } & $\mathrm{MS} 2$ & $68.0 \pm 3.5$ & $13.6 \pm 0.8$ & 214 \\
\hline \multirow{2}{*}{ II } & MS1 & $119.1 \pm 2.5$ & $18.2 \pm 0.4$ & 294 \\
\cline { 2 - 5 } & MS2 & $63.3 \pm 4.5$ & $14.0 \pm 1.1$ & 194 \\
\hline
\end{tabular}




\begin{tabular}{|c|c|c|c|c|}
\hline \multirow{2}{*}{ III } & MS1 & $108.9 \pm 4.7$ & $16.6 \pm 0.8$ & 290 \\
\cline { 2 - 5 } & MS2 & $67.3 \pm 4.6$ & $13.5 \pm 1.1$ & 213 \\
\hline
\end{tabular}

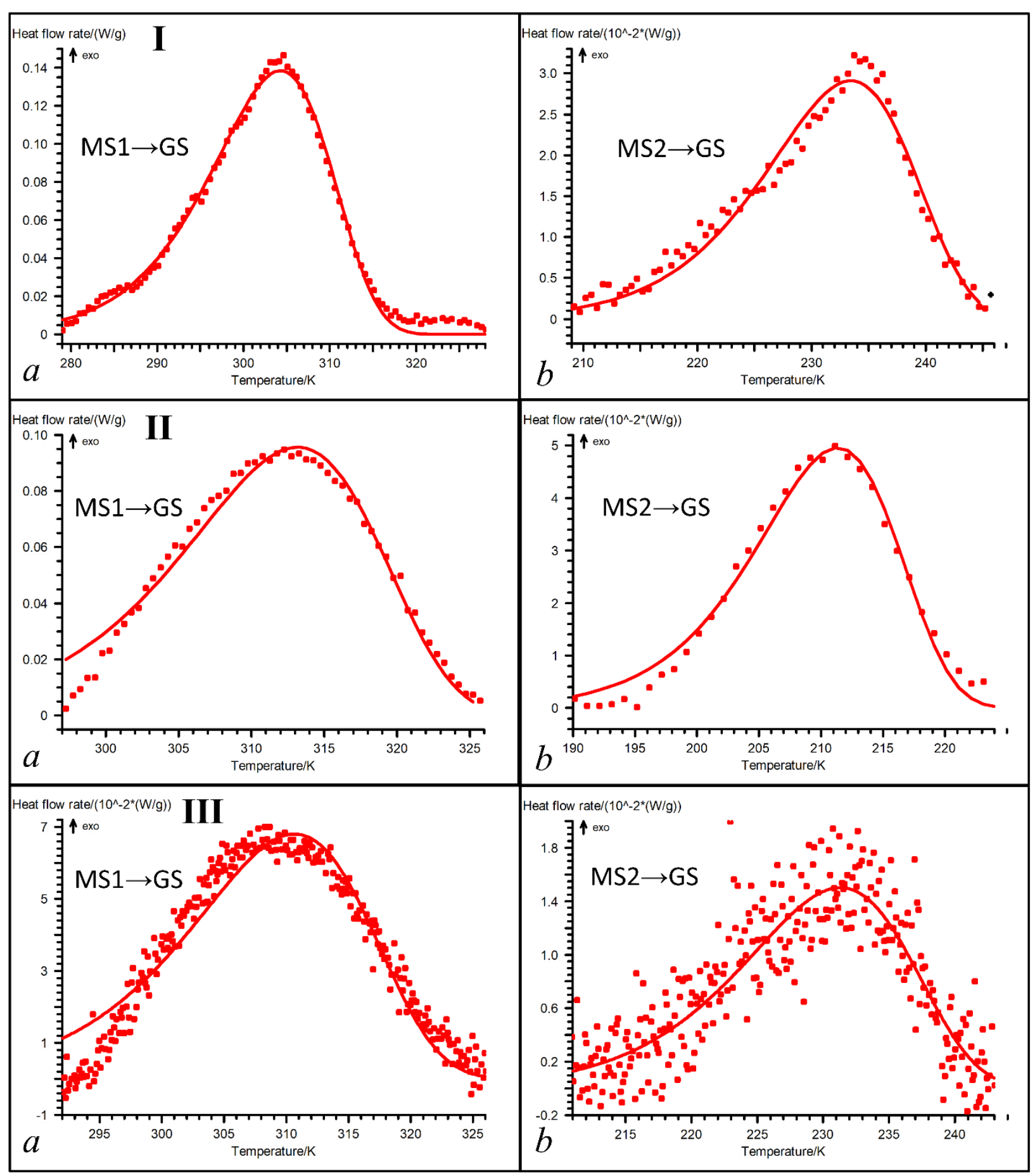

Fig. 6. The DSC curves of the MS1 $\rightarrow \mathrm{GS}$ (panels $a$ ) and MS2 $\rightarrow \mathrm{GS}$ (panels $b$ ) reactions of trans $(\mathrm{NO}, \mathrm{F})-$ $\operatorname{cis}\left(\mathrm{NH}_{3}, \mathrm{NH}_{3}\right)-\left[\mathrm{RuNO}\left(\mathrm{NH}_{3}\right)_{2}\left(\mathrm{H}_{2} \mathrm{O}\right)_{2} \mathrm{~F}\right] \mathrm{SiF} \mathrm{F}_{6}(\mathrm{I})$, trans $(\mathrm{NO}, \mathrm{F})-\operatorname{cis}\left(\mathrm{NH}_{3}, \mathrm{NH}_{3}\right)-\left[\mathrm{RuNO}\left(\mathrm{NH}_{3}\right)_{2} \mathrm{Py}_{2}\left(\mathrm{NO}_{3}\right) \mathrm{F}\right]_{2} \mathrm{SiF}_{6} \cdot \mathrm{H}_{2} \mathrm{O}$ (II) and trans $(\mathrm{NO}, \mathrm{F})-\operatorname{cis}\left(\mathrm{NH}_{3}, \mathrm{NH}_{3}\right)-\left[\mathrm{RuNO}\left(\mathrm{NH}_{3}\right)_{2} \mathrm{Py}\left(\mathrm{H}_{2} \mathrm{O}\right) \mathrm{F}\right]\left(\mathrm{ClO}_{4}\right)_{2}$ (III) measured by the DSC fitted by the kinetic of the first order. 
Going back to the difference of $\mathrm{T}_{\max }$ in I $(270 \mathrm{~K})$, II (220 K) and III (260 K), the higher thermal stabilities of MS2 in I and III provide higher $T_{\max }$ due to the longer lifetime of the MS2 during transformation GS $\rightarrow$ MS2 $\rightarrow$ MS1, which increases the reaction cross section. The calculated lifetimes of MS2 at T $\max$ are $0.4,11$ and $1 \mathrm{~s}$ for I, II and III respectively. Recently it was shown for different ruthenium complexes that the lifetime of MS2 needs to be in the range of some seconds, in order to generate MS1 using irradiation with LED ${ }^{22}$. In terms of the GS $\rightarrow$ MS2 $\rightarrow$ MS1 mechanism of isomerization, at higher temperatures the probability of the second MS2 $\rightarrow$ MS1 transformation decreases due to the decreased lifetime of MS2, which results in the small fraction of MS2 excitation to MS1. Hence, even small increase of the MS2 decay temperature can drastically increase temperature, at which MS1 can be generated.

The analysis of amine and pyridine ruthenium complexes with trans-ON-Ru-F coordinate reveals that for complexes with different first and second coordination spheres, the decay temperatures of MS1 vary in the range 284-307 K (see Table S3) and in the range 185-214 K in case of MS2. Thus, considering rather different composition of the listed complexes (besides keeping trans-ON-Ru-F), the dispersion of decay temperatures of MS1 and MS2 are 23 and $29 \mathrm{~K}$ respectively. A similar dispersion of the MS1 decay temperatures $(27 \mathrm{~K})$ is observed for the family of complexes $\left[\mathrm{RuNOL}_{x}\left(\mathrm{NO}_{2}\right)_{4-\mathrm{x}} \mathrm{OH}\right]^{\mathrm{x}-2}(\mathrm{~L}=\mathrm{N}$-donor heterocyclic ligands), with different type and quantity of the $\mathrm{N}$-donor heterocyclic and nitrite ligands in the equatorial plane ${ }^{56}$. The change of pyridine ligands to amine ligands as well as change of anions $\left(\mathrm{Cl}^{-}\right.$vs. $\left.\mathrm{ClO}_{4}^{-}\right)$drastically modify the thermal stability of the MS1 in a hydroxyl complex $\left(258 \mathrm{~K}\right.$ in case of trans-[RuNO$\left.\left(\mathrm{NH}_{3}\right)_{4} \mathrm{OH}\right] \mathrm{Cl}_{2} \quad 53$ and $212 \mathrm{~K}$ in case of trans$\left.\left[\mathrm{RuNOPy}{ }_{4} \mathrm{OH}\right]\left(\mathrm{ClO}_{4}\right)_{2} \cdot \mathrm{H}_{2} \mathrm{O}{ }^{24}\right)$. According to the study of nitroprusside complexes [FeNO(CN) $\left.)_{5}\right]^{2-}$ with plenty of counterions, the dispersion of decay temperatures of MS1 and MS2 are 38 and $23 \mathrm{~K}$ respectively, for all studied compounds ${ }^{57}$. Thus, retaining the same trans-ON-M-X coordinate, change of both ligand environment and counterion quite sufficiently modify thermal stability of metastable states. Hence, the thermal stability of MS1 and MS2 is probably determined by a more complex pattern, involving intra- and intermolecular interactions. It is challenging task to split the effect of crystal environment of NO and the equatorial ligands to the thermal stability of metastable states.

\section{Conclusions}

The complexes fac- $\left[\mathrm{RuNO}\left(\mathrm{NH}_{3}\right)_{2}\left(\mathrm{NO}_{3}\right)_{3}\right]$ and trans- $\left(\mathrm{NO}, \mathrm{NO}_{3}\right)$-cis- $\left(\mathrm{NH}_{3}, \mathrm{NH}_{3}\right)-\left[\mathrm{RuNO}\left(\mathrm{NH}_{3}\right)_{2} \mathrm{Py} 2\left(\mathrm{NO}_{3}\right)\right]\left(\mathrm{NO}_{3}\right)_{2} \cdot \mathrm{H}_{2} \mathrm{O}$ are convenient precursors for the nitrate ligands substitution. The reaction of the complexes with hydrofluoric acid leads to the selective coordination of the fluoride ligand to the trans-position to NO ligand. In case of fac[RuNO $\left.\left(\mathrm{NH}_{3}\right)_{2}\left(\mathrm{NO}_{3}\right)_{3}\right]$ the substitution by $\mathrm{F}^{-}$occurs only in one position, while $\mathrm{NO}_{3}{ }^{-}$in the equatorial plane are substituted by the water molecules. Surprisingly, in case of trans- $\left(\mathrm{NO}^{-N_{3}}\right)-$ cis- $\left(\mathrm{NH}_{3}, \mathrm{NH}_{3}\right)^{-}$ $\left[\mathrm{RuNO}\left(\mathrm{NH}_{3}\right)_{2} \mathrm{Py}_{2}\left(\mathrm{NO}_{3}\right)\right]\left(\mathrm{NO}_{3}\right)_{2}$ the reaction with $\mathrm{HF}$ additionally results in the pyridine ligand elimination by the water or nitrate ligand. The structures of the obtained complexes trans(NO,F)-cis $\left(\mathrm{NH}_{3}, \mathrm{NH}_{3}\right)$ $\left[\operatorname{RuNO}\left(\mathrm{NH}_{3}\right)_{2}\left(\mathrm{H}_{2} \mathrm{O}\right)_{2} \mathrm{~F}\right] \mathrm{SiF}_{6}$ (I), trans(NO,F)-cis $\left(\mathrm{NH}_{3}, \mathrm{NH}_{3}\right)-\left[\mathrm{RuNO}\left(\mathrm{NH}_{3}\right)_{2} \mathrm{Py}\left(\mathrm{NO}_{3}\right) \mathrm{F}\right]_{2} \mathrm{SiF}_{6} \cdot \mathrm{H}_{2} \mathrm{O}$ (II) and trans $(\mathrm{NO}, \mathrm{F})-$ $\operatorname{cis}\left(\mathrm{NH}_{3}, \mathrm{NH}_{3}\right)-\left[\mathrm{RuNO}\left(\mathrm{NH}_{3}\right)_{2} \mathrm{Py}\left(\mathrm{H}_{2} \mathrm{O}\right) \mathrm{F}\right]\left(\mathrm{ClO}_{4}\right)_{2}$ (III) were determined by X-ray diffraction. In addition, the complex 
III tends to produce a rare dimeric complex trans(NO,F)-cis $\left.\left(\mathrm{NH}_{3}, \mathrm{NH}_{3}\right)-\left[\left(\operatorname{RuNOPy}\left(\mathrm{NH}_{3}\right)_{2} \mathrm{~F}\right)_{2}\left(\mu-\mathrm{O}_{2} \mathrm{H}_{3}\right)\right](\mathrm{ClO})_{3}\right)_{3}$ (IV), which structure was as well revealed by $\mathrm{X}$-ray diffraction. The photochemical investigation reveals the reversible formation of the Ru-ON (MS1) and Ru- $\eta^{2}$-(NO) (MS2) isomers in I, II and III after light irradiation of Ru-NO (GS), as evidenced by IR spectroscopy and DSC. The metastable states possess rather high thermal stability due to the fluoride ligand in trans-position to NO ligand. The influence of the equatorial ligands to the properties of linkage isomers is less evident. On one hand, the introduction of water ligands to the equatorial plane of the complex increases the thermal stability of MS2, on the other hand, it slightly decreases the stability of the MS1. Moreover, the change of the thermal stability likely can also be referred to the difference in crystal environment of nitrosyl ligand. Thus, the thermal stability of MS1 and MS2 is probably determined by a more complex pattern, involving intra- and intermolecular interactions. This can even lead to opposite effects, i.e. increasing thermal stability of MS1 while decreasing thermal stability of MS2, as found for II. The higher thermal stability of MS2 is crucial in view for the design of potential applications based on the metastable states, since it leads to a higher photogeneration temperature of MS1. A further positive effect of the introduction of pyridine as equatorial ligand is the increase in achievable population of MS1 and MS2.

\section{Acknowledgement}

The investigation was supported by Russian Basic Research Foundation (Project 19-03-00594). Artem Mikhailov is grateful for financial support from the Eiffel excellence bourse program (Grant P730329G). We thank the PMD ${ }^{2} X X$-ray diffraction facility of the Institut Jean Barriol, Universite de Lorraine and XRD Facility of NIIC SB RAS for X-ray diffraction measurements.

\section{References}

1 J. Akl, C. Billot, P. G. Lacroix, I. Sasaki, S. Mallet-Ladeira, I. Malfant, R. Arcos-Ramos, M. Romero and N. Farfán, New J. Chem., 2013, 37, 3518-3527.

2 A. Mikhailov, V. Vuković, C. Kijatkin, E. Wenger, M. Imlau, T. Woike, G. Kostin and D. Schaniel, Acta Crystallogr. Sect. B Struct. Sci. Cryst. Eng. Mater., 2019, 75, 1152-1163.

3 G. A. Kostin, A. O. Borodin, N. V. Kuratieva, A. S. Bogomyakov and A. A. Mikhailov, Inorganica Chim. Acta, 2018, 479, 135-140.

$4 \quad$ R. B. Morgunov, A. I. Dmitriev, F. B. Mushenok, É. B. Yagubskiĭ, L. A. Kushch, A. R. Mustafina, V. A. Burilov, A. T. Gubaĭdullin, A. I. Konovalov, I. S. Antipin and Y. Tanimoto, Phys. Solid State, 2009, 51, 2095-2100.

5 D. Schaniel, M. Imlau, T. Weisemoeller, T. Woike, K. W. Krämer and H.-U. Güdel, Adv. Mater., 2007, 19, 723-726.

6 M. J. Rose and P. K. Mascharak, Coord. Chem. Rev., 2008, 252, 2093-2114.

7 A. B. Seabra, G. Z. Justo and P. S. Haddad, Biotechnol. Adv., 2015, 33, 1370-1379.

8 E. O'Toole, M. V. Doucet, E. Sherwin and A. Harkin, in Systems Neuroscience in Depression, Elsevier, 2016, pp. 81-113.

9 S. Hasan, N. Thomas, B. Thierry and C. A. Prestidge, J. Mater. Chem. B, 2017, 5, 1005-1014. 
A. B. Seabra and N. Durán, in Nitric Oxide Donors, Elsevier, 2017, pp. 25-53.

N. C. Adusumilli, D. Zhang, J. M. Friedman and A. J. Friedman, Nitric Oxide, 2020, 103, 4-8.

S. Åkerström, M. Mousavi-Jazi, J. Klingström, M. Leijon, A. Lundkvist and A. Mirazimi, J. Virol., 2005, 79, 1966-1969.

S. Åkerström, V. Gunalan, C. T. Keng, Y.-J. Tan and A. Mirazimi, Virology, 2009, 395, 1-9.

J. C. Pieretti, O. Rubilar, R. B. Weller, G. R. Tortella and A. B. Seabra, Virus Res., 2021, 291, 198202.

J. S. García, F. Alary, M. Boggio-Pasqua, I. M. Dixon and J.-L. Heully, J. Mol. Model., 2016, 22, 284.

P. Coppens, I. Novozhilova and A. Kovalevsky, Chem. Rev., 2002, 102, 861-884.

D. Schaniel, B. Cormary, I. Malfant, L. Valade, T. Woike, B. Delley, K. W. Krämer and H. U. Güdel, Phys. Chem. Chem. Phys., 2007, 9, 3717-3724.

T. E. Bitterwolf, Coord. Chem. Rev., 2006, 250, 1196-1207.

Y. Morioka, A. Ishikawa, H. Tomizavva and E. I. Miki, J. Chem. Soc. Dalt. Trans., 2000, 781-786.

G. A. Kostin, A. A. Mikhailov, N. V Kuratieva, D. P. Pishchur and A. N. Makhinya, New J. Chem., 2018, 42, 18928-18934.

A. A. Mikhailov, V. Y. Komarov, A. S. Sukhikh, D. P. Pishchur, D. Schaniel and G. A. Kostin, New J. Chem., 2020, 44, 18014-18024.

A. A. Mikhailov, E. Wenger, G. A. Kostin and D. Schaniel, Chem. - A Eur. J., 2019, 25, 7569-7574.

R. D. Yamaletdinov and I. L. Zilberberg, Eur. J. Inorg. Chem., 2017, 23, 2951-2954.

V. Vorobyev, A. A. Mikhailov, V. Y. Komarov, A. N. Makhinya and G. A. Kostin, New J. Chem., 2020, 44, 4762-4771.

25 E. Orlowska, M. V. Babak, O. Dömötör, E. A. Enyedy, P. Rapta, M. Zalibera, L. Bučinský, M. Malček, C. Govind, V. Karunakaran, Y. C. S. Farid, T. E. McDonnell, D. Luneau, D. Schaniel, W. H. Ang and V. B. Arion, Inorg. Chem., 2018, 57, 10702-10717.

26 A. Rathgeb, A. Böhm, M. S. Novak, A. Gavriluta, O. Dömötör, J. B. Tommasino, É. A. Enyedy, S. Shova, S. Meier, M. A. Jakupec, D. Luneau and V. B. Arion, Inorg. Chem., 2014, 53, 2718-2729.

27 M. A. II'in, A. N. Makhinya, I. A. Baidina and S. V. Tkachev, Inorganica Chim. Acta, 2014, 413, 9096.

28 P. Labra-Vázquez, M. Bocé, M. Tassé, S. Mallet-Ladeira, P. G. Lacroix, N. Farfán and I. Malfant, Dalt. Trans., 2020, 49, 3138-3154.

29 T. Hirano, K. Ueda, M. Mukaida, H. Nagao and T. Oi, J. Chem. Soc. Dalt. Trans., 2001, 2, 23412345.

30 A. V Belyaev, V. A. Emel'yanov, S. P. Khranenko and M. A. Fedotov, Russ. J. Coord. Chem., 1996, 22, 358-359.

31 V. Vorobyev, G. A. Kostin, N. V. Kuratieva and V. A. Emelyanov, Inorg. Chem., 2016, 55, 91589161.

32 V. Vorobyev, G. A. Kostin, I. A. Baidina, A. A. Mikhailov, I. V. Korolkov and V. A. Emelyanov, Zeitschrift für Anorg. und Allg. Chemie, 2020, 646, 58-64.

G. A. Kostin, Y. A. Nikiforov and N. V. Kuratieva, J. Struct. Chem., 2020, 61, 86-94. 
E. V. Kabin, V. A. Emel'yanov, V. A. Vorob'yev, N. I. Alferova, S. V. Tkachev and I. A. Baidina, Russ. J. Inorg. Chem., 2012, 57, 1146-1153.

G. M. Sheldrick, Acta Crystallogr. Sect. A Found. Adv., 2015, 71, 3-8.

O. V. Dolomanov, L. J. Bourhis, R. J. Gildea, J. A. K. Howard and H. Puschmann, J. Appl. Crystallogr., 2009, 42, 339-341.

F. L. Hirshfeld, Theor. Chim. Acta, 1977, 44, 129-138.

M. A. Spackman and D. Jayatilaka, CrystEngComm, 2009, 11, 19-32.

J. H. Enemark and R. D. Feltham, Coord. Chem. Rev., 1974, 13, 339-406.

V. A. Emel'yanov, E. V Kabin and I. A. Baidina, J. Struct. Chem., 2009, 50, 577-581.

R. Schneider, T. Weyhermueller, K. Wieghardt and B. Nuber, Inorg. Chem., 1993, 32, 4925-4934.

L. Duan, A. Fischer, Y. Xu and L. Sun, J. Am. Chem. Soc., 2009, 131, 10397-10399.

T. Jüstel, J. Bendix, N. Metzler-Nolte, T. Weyhermüller, B. Nuber and K. Wieghardt, Inorg. Chem., 1998, 37, 35-43.

T. Hirano, M. Kuroda, N. Takeda, M. Hayashi, M. Mukaida, T. Oi and H. Nagao, J. Chem. Soc. Dalt. Trans., 2002, 2158-2162.

F. Bozoglian, S. Romain, M. Z. Ertem, T. K. Todorova, C. Sens, J. Mola, M. Rodríguez, I. Romero, J. Benet-Buchholz, X. Fontrodona, C. J. Cramer, L. Gagliardi and A. Llobet, J. Am. Chem. Soc., 2009, 131, 15176-15187.

47 B. Cormary, I. Malfant, M. Buron-Le Cointe, L. Toupet, B. Delley, D. Schaniel, N. Mockus, T. Woike, K. Fejfarová, V. Petříček and M. Dušek, Acta Crystallogr. Sect. B Struct. Sci., 2009, 65, 612-623.

Y. Morioka, A. Ishikawa, H. Tomizawa and E. Miki, J. Chem. Soc. Dalt. Trans., 2000, 54, 781-786.

D. Schaniel and T. Woike, Phys. Chem. Chem. Phys., 2009, 11, 4298-4359.

B. Cormary, S. Ladeira, K. Jacob, P. G. Lacroix, T. Woike, D. Schaniel and I. Malfant, Inorg. Chem., 2012, 51, 7492-7501.

L. Khadeeva, W. Kaszub, M. Lorenc, I. Malfant and M. Buron-Le Cointe, Inorg. Chem., 2016, 55, 4117-4123.

D. Schaniel, T. Woike, C. Boskovic and H. U. Güdel, Chem. Phys. Lett., 2004, 390, 347-351.

D. Schaniel, T. Woike, B. Delley, C. Boskovic, D. Biner, K. W. Krämer and H. U. Güdel, Phys. Chem. Chem. Phys., 2005, 7, 1164-1170. 471-475.

56 A. A. Mikhailov, D. P. Pishchur, N. V. Kuratieva and G. A. Kostin, Mendeleev Commun., 2020, 30, 719-721.

H. Zöllner, W. Krasser, T. Woike and S. Haussühl, Chem. Phys. Lett., 1989, 161, 497-501. 

The nitrosyl linkage photoisomerization in heteroleptic fluoride ruthenium complexes derived from labile nitrate precursors

Artem A. Mikhailov ${ }^{a}$, Vladislav Yu. Komarova ${ }^{a}$ Denis P. Pishchur ${ }^{a}$, Dominik Schaniel ${ }^{b}$ and Gennadiy A. Kostin ${ }^{a}$

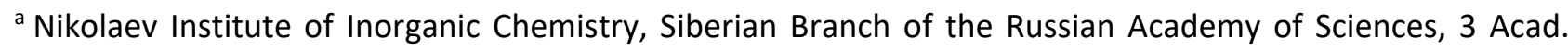
Lavrentiev Avenue, Novosibirsk 630090, Russian Federation

b Universite' de Lorraine, CNRS, CRM2, UMR 7036, Nancy 54000, France

Table S1. Experimental and refinement details.

\begin{tabular}{|c|c|c|c|c|}
\hline Complex & $\begin{array}{c}{\left[\mathrm{RuNO}\left(\mathrm{NH}_{3}\right)_{2}\left(\mathrm{H}_{2} \mathrm{O}\right)_{2} \mathrm{~F}\right]} \\
\mathrm{SiF}_{6}\end{array}$ & $\begin{array}{c}{\left[\mathrm{RuNOPy}\left(\mathrm{NH}_{3}\right)_{2}\left(\mathrm{NO}_{3}\right) \mathrm{F}\right]_{2}} \\
\mathrm{SiF}_{6} \cdot \mathrm{H}_{2} \mathrm{O}\end{array}$ & $\begin{array}{c}{\left[\text { RuNOPy }\left(\mathrm{NH}_{3}\right)_{2}\left(\mathrm{H}_{2} \mathrm{O}\right) \mathrm{F}\right]} \\
\left(\mathrm{ClO}_{4}\right)_{2}\end{array}$ & $\begin{array}{c}{\left[\left(\mathrm{RuNOPy}\left(\mathrm{NH}_{3}\right)_{2} \mathrm{~F}\right)_{2}\right.} \\
\left.\left(\mu-\mathrm{O}_{2} \mathrm{H}_{3}\right)\right]\left(\mathrm{ClO}_{4}\right)_{3}\end{array}$ \\
\hline $\begin{array}{l}\text { Empirical } \\
\text { formula }\end{array}$ & $\mathrm{F}_{7} \mathrm{H}_{10} \mathrm{~N}_{3} \mathrm{O}_{3} \mathrm{RuSi}$ & $\mathrm{C}_{10} \mathrm{H}_{26} \mathrm{~F}_{8} \mathrm{~N}_{10} \mathrm{O}_{10} \mathrm{Ru}_{2} \mathrm{Si}$ & $\mathrm{C}_{5} \mathrm{H}_{13} \mathrm{Cl}_{2} \mathrm{FN}_{4} \mathrm{O}_{10} \mathrm{Ru}$ & $\begin{array}{c}\mathrm{C}_{6.67} \mathrm{H}_{16.67} \mathrm{Cl}_{2} \mathrm{~F}_{1.33} \mathrm{~N}_{5.33} \mathrm{O}_{10.67} \\
\mathrm{Ru}_{1.33}\end{array}$ \\
\hline Formula weight & 362.27 & 828.64 & 480.16 & 573.25 \\
\hline Temperature/K & 150 & 150 & 150 & 100 \\
\hline Crystal system & orthorhombic & triclinic & monoclinic & monoclinic \\
\hline Space group & Pnma & P-1 & $\mathrm{P} 2_{1} / \mathrm{c}$ & $\mathrm{P} 2_{1} / \mathrm{c}$ \\
\hline $\mathrm{a} / \AA ̊ \AA$ & $19.2150(5)$ & $6.7669(3)$ & $18.3073(8)$ & $18.6327(8)$ \\
\hline $\mathrm{b} / \AA ̊ \AA$ & $7.7578(3)$ & $9.2867(4)$ & $8.3396(3)$ & $13.8821(5)$ \\
\hline$c / \AA$ & $6.2397(2)$ & $11.4450(6)$ & $10.2007(4)$ & $10.4352(5)$ \\
\hline$\alpha /^{\circ}$ & 90 & $103.780(2)$ & 90 & 90 \\
\hline$\beta /^{\circ}$ & 90 & $101.152(2)$ & $104.729(2)$ & $96.730(4)$ \\
\hline$\gamma /{ }^{\circ}$ & 90 & $103.764(2)$ & 90 & 90 \\
\hline Volume/ $/ \AA^{3}$ & $930.13(5)$ & $654.19(5)$ & $1506.22(10)$ & $2680.6(2)$ \\
\hline$Z$ & 4 & 1 & 4 & 6 \\
\hline$\rho_{\text {calc }} \mathrm{g} / \mathrm{cm}^{3}$ & 2.587 & 2.103 & 2.117 & 2.131 \\
\hline$\mu / \mathrm{mm}^{-1}$ & 1.924 & 1.323 & 1.465 & 1.526 \\
\hline$F(000)$ & 704.0 & 410.0 & 952.0 & 1704.0 \\
\hline $\begin{array}{c}\text { Crystal } \\
\text { size } / \mathrm{mm}^{3}\end{array}$ & $0.388 \times 0.369 \times 0.194$ & $0.137 \times 0.107 \times 0.059$ & $0.284 \times 0.145 \times 0.091$ & $0.036 \times 0.021 \times 0.012$ \\
\hline Radiation & $\operatorname{MoK} \alpha(\lambda=0.71073)$ & $\operatorname{MoK} \alpha(\lambda=0.71073)$ & $\operatorname{MoK} \alpha(\lambda=0.71073)$ & $\operatorname{MoK} \alpha(\lambda=0.71073)$ \\
\hline $\begin{array}{l}2 \Theta \text { range for } \\
\text { data collection }{ }^{\circ}\end{array}$ & 4.24 to 59.318 & 3.8 to 61.44 & 4.602 to 63.002 & 4.402 to 65.83 \\
\hline Index ranges & $\begin{array}{c}-24 \leq h \leq 26 \\
-10 \leq k \leq 9 \\
-8 \leq 1 \leq 5\end{array}$ & $\begin{array}{r}-9 \leq h \leq 9 \\
-13 \leq k \leq 13 \\
-15 \leq 1 \leq 15\end{array}$ & $\begin{array}{l}-26 \leq h \leq 22 \\
-11 \leq k \leq 12 \\
-14 \leq 1 \leq 13\end{array}$ & $\begin{array}{l}-28 \leq h \leq 27 \\
-21 \leq k \leq 20 \\
-15 \leq 1 \leq 14\end{array}$ \\
\hline $\begin{array}{l}\text { Reflections } \\
\text { collected }\end{array}$ & 4440 & 12459 & 22377 & 44028 \\
\hline $\begin{array}{l}\text { Independent } \\
\text { reflections }\end{array}$ & $\begin{array}{c}1406\left[R_{\text {int }}=0.0238,\right. \\
\left.R_{\text {sigma }}=0.0248\right]\end{array}$ & $\begin{array}{c}3865\left[R_{\text {int }}=0.0312, R_{\text {sigma }}=\right. \\
0.0368]\end{array}$ & $\begin{array}{c}5005\left[R_{\text {int }}=0.0513,\right. \\
\left.R_{\text {sigma }}=0.0442\right]\end{array}$ & $\begin{array}{c}9455\left[R_{\text {int }}=0.0597, R_{\text {sigma }}=\right. \\
0.0543]\end{array}$ \\
\hline $\begin{array}{c}\text { Data/restraints/ } \\
\text { parameters }\end{array}$ & $1406 / 0 / 82$ & $3865 / 0 / 193$ & $5005 / 0 / 244$ & $9455 / 1 / 380$ \\
\hline $\begin{array}{l}\text { Goodness-of-fit } \\
\text { on } F^{2}\end{array}$ & 1.262 & 1.056 & 1.123 & 1.071 \\
\hline $\begin{array}{l}\text { Final } R \text { indexes } \\
{[1>=2 \sigma(I)]}\end{array}$ & $\begin{array}{c}R_{1}=0.0272, w R_{2}= \\
0.0542\end{array}$ & $\mathrm{R}_{1}=0.0238, \mathrm{wR}_{2}=0.0442$ & $\begin{array}{c}\mathrm{R}_{1}=0.0404, \mathrm{wR}_{2}= \\
0.0785\end{array}$ & $R_{1}=0.0395, w_{2}=0.0758$ \\
\hline $\begin{array}{l}\text { Final } R \text { indexes } \\
\text { [all data] }\end{array}$ & $\begin{aligned} R_{1} & =0.0284 \\
w R_{2} & =0.0546\end{aligned}$ & $\begin{aligned} R_{1} & =0.0285 \\
W R_{2} & =0.0458\end{aligned}$ & $\begin{aligned} \mathrm{R}_{1} & =0.0489 \\
\mathrm{wR}_{2} & =0.0821\end{aligned}$ & $\begin{aligned} R_{1} & =0.0701 \\
w R_{2} & =0.0924\end{aligned}$ \\
\hline $\begin{array}{l}\text { Largest diff. } \\
\text { peak/hole / e } \AA^{-} \\
3\end{array}$ & $0.42 /-0.89$ & $0.48 /-0.66$ & $0.61 /-0.74$ & $1.93 /-1.40$ \\
\hline
\end{tabular}


The Hirshfeld surfaces were calculated using Crystal Explorer ${ }^{1,2}$. This program allows the normalized contact distance $d_{n o r m}$ to be mapped onto the generated Hirshfeld surface. It is customary to map $d_{\text {norm }}$ using a redwhite-blue scheme, where red denotes close intermolecular contacts (negative $d_{\text {norm }}$ ), blue denotes longer contacts (positive $d_{n o r m}$ ) and white denotes intermolecular contacts equal to the van der Waals radii of atoms in contact $\left(d_{\text {norm }}=0\right)$. It is possible to obtain two-dimensional plots (fingerprint plots) from the surfaces mapped with $d_{\text {norm }}$ values. Derived from the Hirshfeld surface, these 2D-fingerprint plots provide a visual summary of the frequency of each combination of $d_{e}$ (radius of external atom) and $d_{i}$ (radius of internal atom) across the surface of a molecule, so they not only indicate which intermolecular interactions are present, but also the relative area of the surface corresponding to each kind of interaction. Points on the plot with no contribution on the surface are left uncoloured, and points with a contribution to the surface are coloured blue for a small contribution through green to red for points with the greatest contribution.

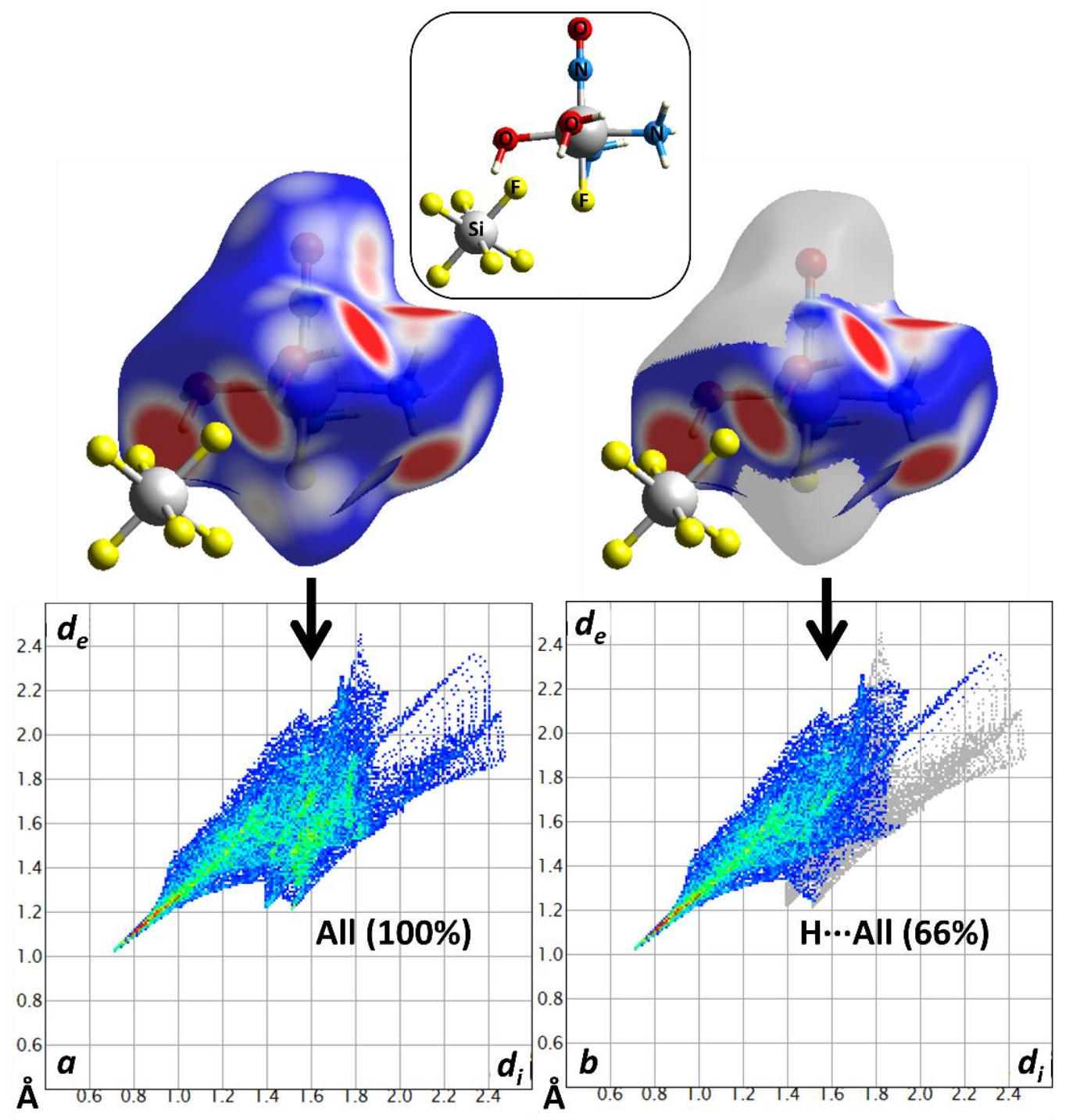

Fig. S1. The panel $a$ represents the total Hirshfeld surface of the $\left[\mathrm{RuNO}\left(\mathrm{NH}_{3}\right)_{2}\left(\mathrm{H}_{2} \mathrm{O}\right)_{2} \mathrm{~F}\right]^{2+}$ cation and corresponding two-dimensional fingerprint. The panel $b$ shows the surface formed by the contacts of hydrogen atoms with other surrounding atoms and corresponding $2 \mathrm{D}$ fingerplot. 


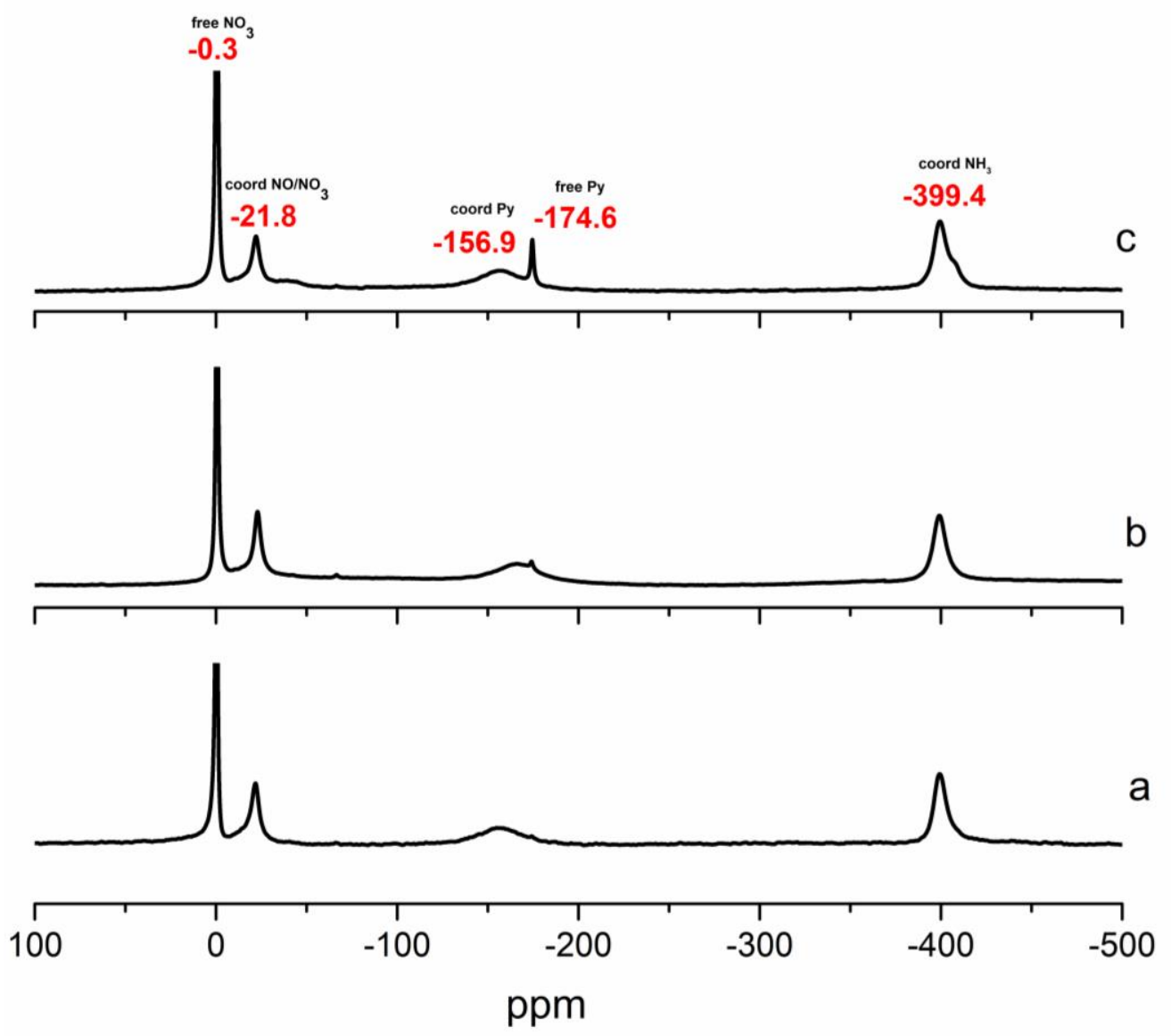

Fig. S2. ${ }^{14} \mathrm{~N}$ - NMR spectra of water solution of $\left[\mathrm{RuNO}\left(\mathrm{NH}_{3}\right)_{2}(\mathrm{Py})_{2}\left(\mathrm{NO}_{3}\right)\right]\left(\mathrm{NO}_{3}\right)_{2}:$ a) immediately after preparation of the solution; b) after 10 days at room temperature; c) after heating for $4 \mathrm{~h}$ at $85^{\circ} \mathrm{C}$.

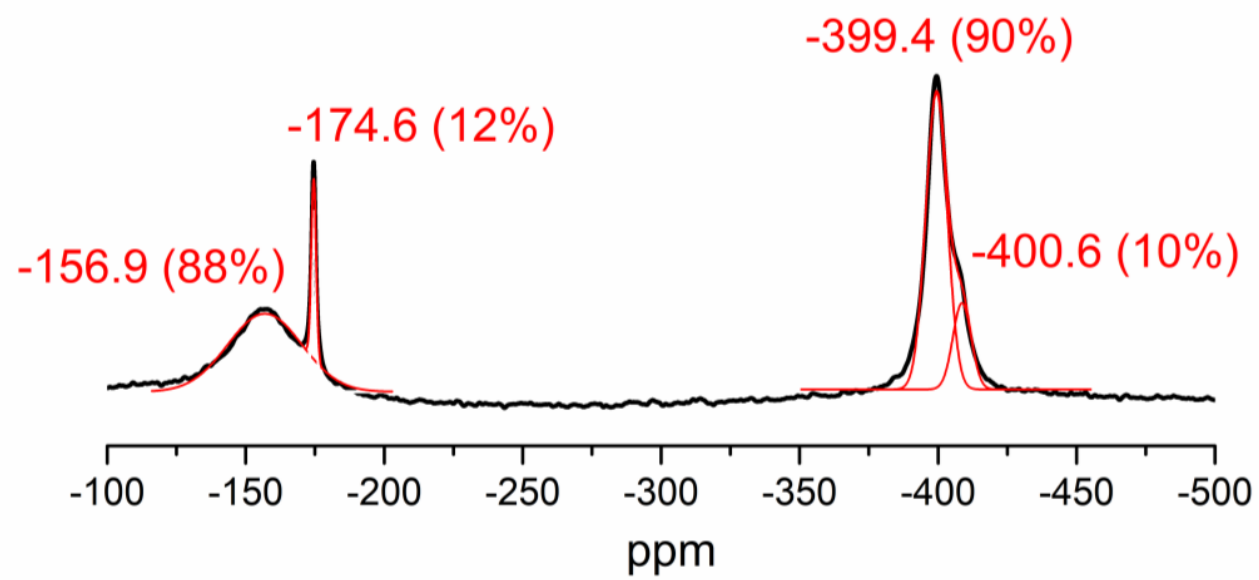

Fig. S3. The Gaussian fit of the peaks of the spectra of the $\left[\mathrm{RuNO}\left(\mathrm{NH}_{3}\right)_{2}(\mathrm{Py})_{2}\left(\mathrm{NO}_{3}\right)\right]\left(\mathrm{NO}_{3}\right)_{2}$ after the heating $(4$ $\left.h, 85^{\circ} \mathrm{C}\right)$. 


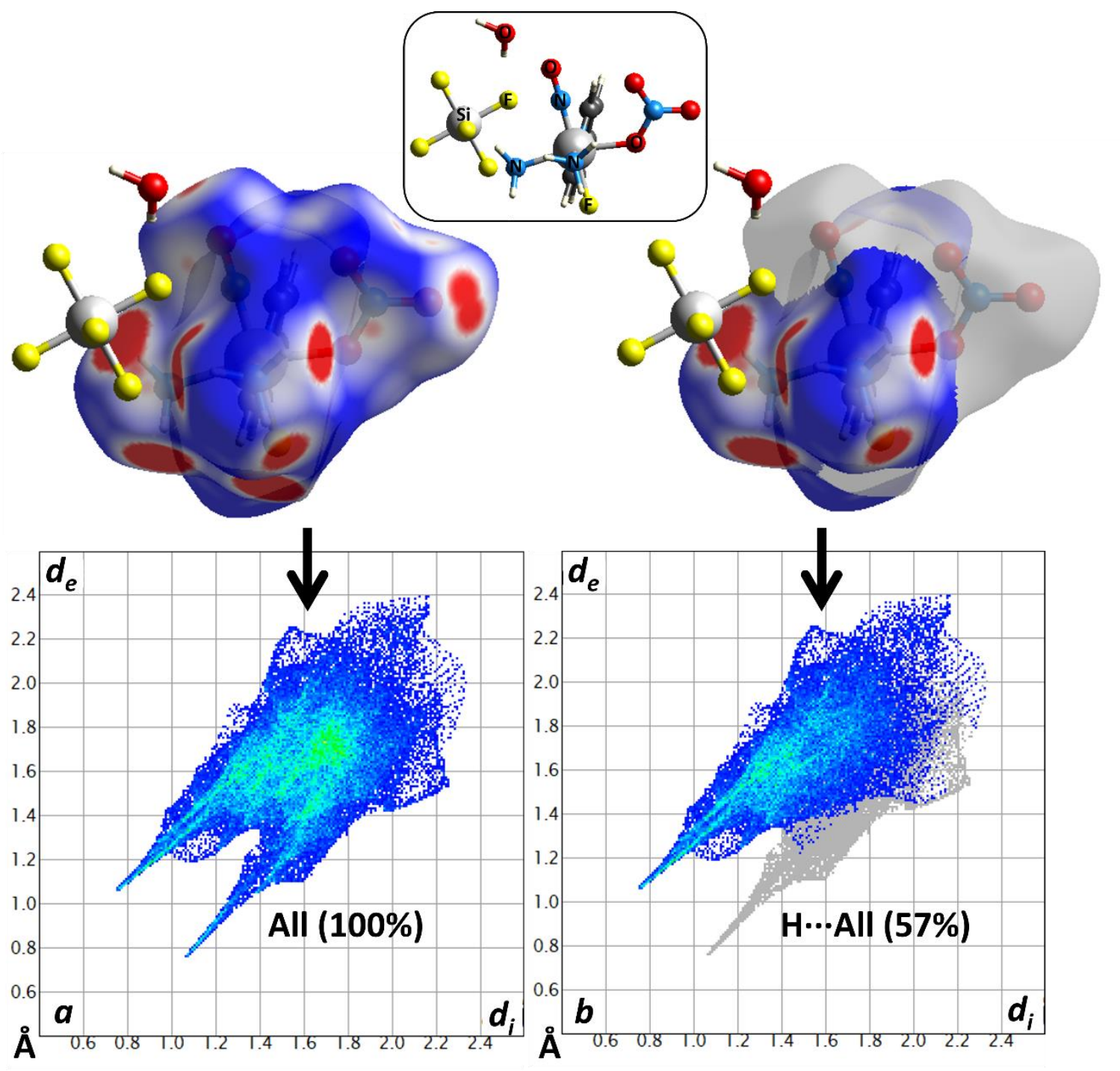

Fig. S4. The panel $a$ represents the total Hirshfeld surface of the $\left[\mathrm{RuNO}\left(\mathrm{NH}_{3}\right)_{2} \mathrm{Py}\left(\mathrm{NO}_{3}\right) \mathrm{F}\right]^{+}$cation and corresponding two-dimensional fingerprint. The panel $b$ shows the surface formed by the contacts of hydrogen atoms with other surrounding atoms and corresponding 2D fingerplot. 


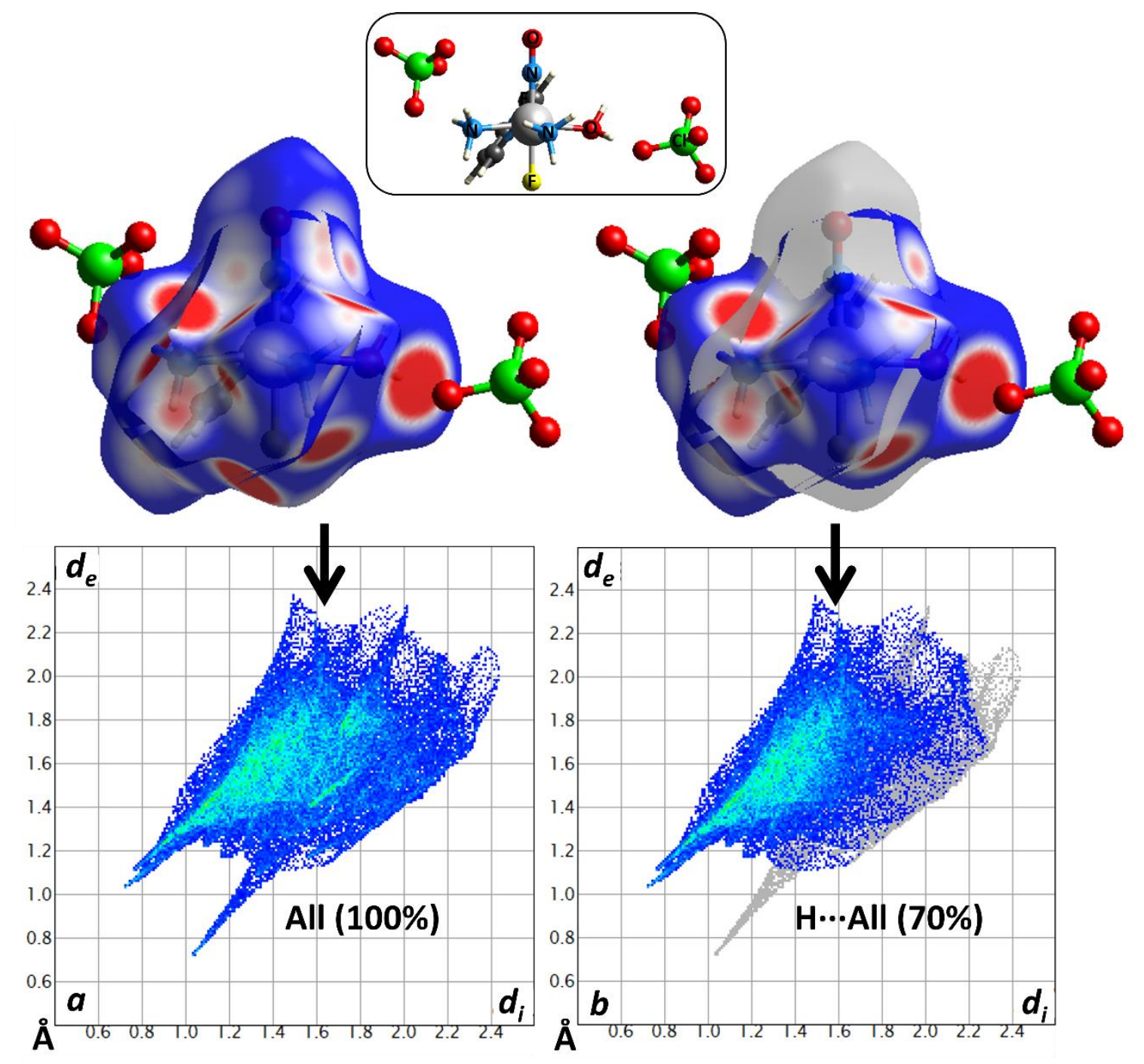

Fig. S5. The panel $a$ represents the total Hirshfeld surface of the $\left[\mathrm{RuNO}\left(\mathrm{NH}_{3}\right)_{2} \mathrm{Py}\left(\mathrm{H}_{2} \mathrm{O}\right) \mathrm{F}\right]^{2+}$ cation and corresponding two-dimensional fingerprint. The panel $b$ shows the surface formed by the contacts of hydrogen atoms with other surrounding atoms and corresponding 2D fingerplot. 


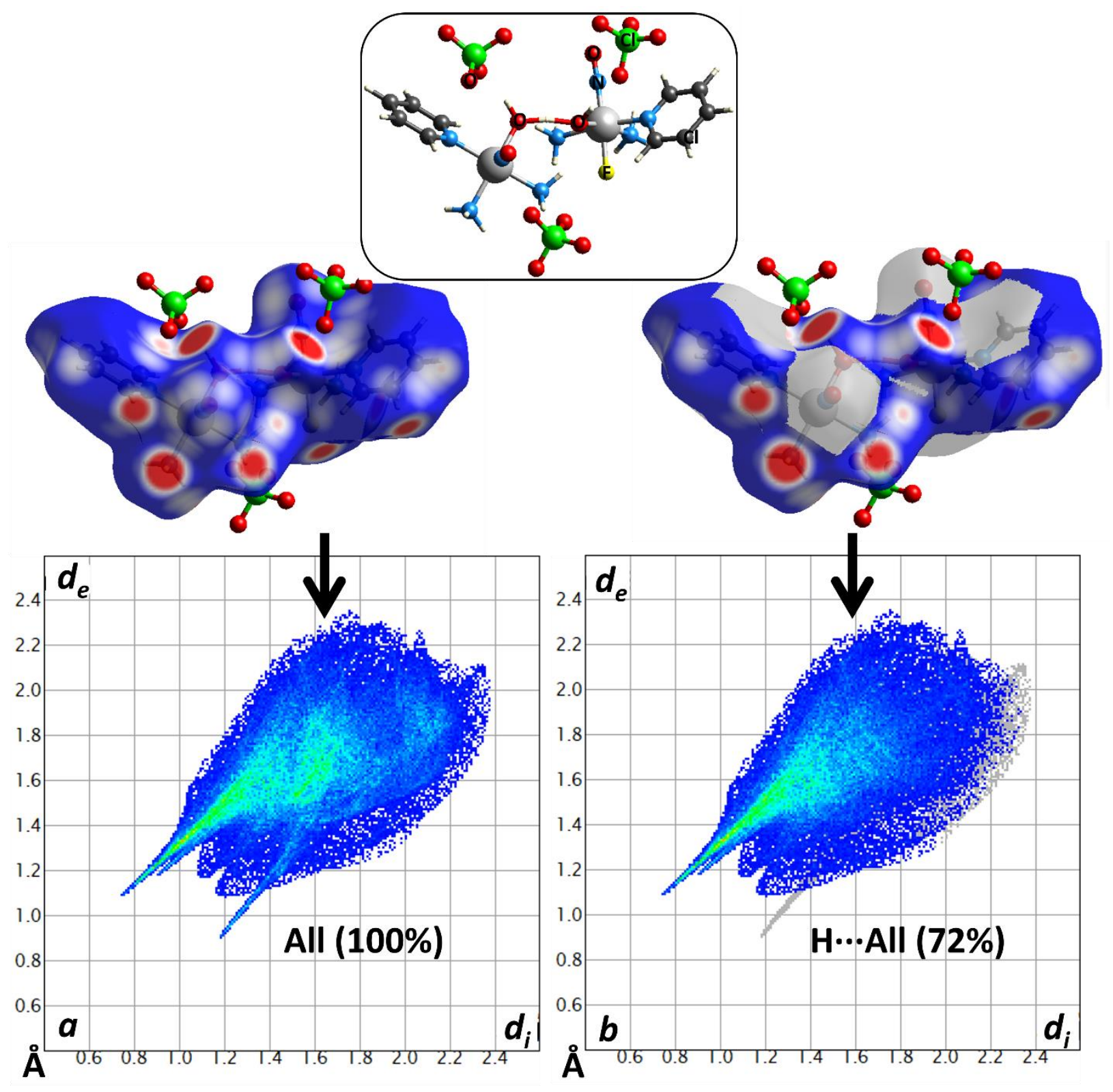

Fig. S6. The panel $a$ represents the total Hirshfeld surface of the $\left[\left(\operatorname{RuNOPy}\left(\mathrm{NH}_{3}\right)_{2} \mathrm{~F}\right)_{2}\left(\mu-\mathrm{O}_{2} \mathrm{H}_{3}\right)\right]^{3+}$ cation and corresponding two-dimensional fingerprint. The panel $b$ shows the surface formed by the contacts of hydrogen atoms with other surrounding atoms and corresponding 2D fingerplot.

Table S2. Intermolecular contacts of NO shorter than the sum of the van der Waals radii (contacting atoms are underlined).

\begin{tabular}{|c|c|c|c|c|c|}
\hline \multicolumn{2}{|c|}{1} & \multicolumn{2}{|c|}{ II } & \multicolumn{2}{|c|}{ III } \\
\hline $\mathrm{NO} \cdots \mathrm{F}$ & 2.85 & NO $\cdots F$ & 2.95 & NO $\cdots O$ & 2.97 \\
\hline $\mathrm{NO} \cdots \mathrm{F}$ & 2.85 & NO $\cdots O$ & 2.84 & NO $\cdots O$ & 3.00 \\
\hline NO $\cdots F$ & 2.87 & NO $\cdots O$ & 2.97 & NO $\cdots O$ & 3.01 \\
\hline NO $\cdots \mathrm{F}$ & 2.87 & NOE $\cdots C$ & 3.10 & & \\
\hline & & NOE $\cdots C$ & 3.11 & & \\
\hline & & NO $\cdots O$ & 2.87 & & \\
\hline
\end{tabular}


Table S3. The positions of $v(N O)$ bands of GS, MS1 and MS2; populations of MS1 and MS2; decay temperatures $\left(T_{d}\right)$ of MS1 and MS2 in the different complexes with trans-ON-Ru-F coordinate.

\begin{tabular}{|c|c|c|c|c|c|c|c|c|}
\hline & $\begin{array}{c}\mathrm{v}(\mathrm{NO})_{\mathrm{GS}} \\
\mathrm{cm}^{-1}\end{array}$ & $\begin{array}{c}\mathrm{v}(\mathrm{NO})_{\mathrm{MS1}} \\
\mathrm{cm}^{-1}\end{array}$ & $\begin{array}{c}\mathrm{v}(\mathrm{NO})_{\mathrm{MS} 2} \\
\mathrm{~cm}^{-1}\end{array}$ & $\begin{array}{c}\text { MS1, } \\
\%\end{array}$ & $\begin{array}{c}\text { MS2, } \\
\%\end{array}$ & $\begin{array}{c}\mathrm{T}_{\mathrm{d}}(\mathrm{MS} 1), \\
\mathrm{K}\end{array}$ & $\begin{array}{c}\mathrm{T}_{\mathrm{d}}(\mathrm{MS} 2) \\
\mathrm{K}\end{array}$ & Ref. \\
\hline$\left[\mathrm{RuNO}\left(\mathrm{NH}_{3}\right)_{2}\left(\mathrm{H}_{2} \mathrm{O}\right)_{2} \mathrm{~F}\right] \mathrm{SiF}_{6}$ & 1914 & 1778 & 1565 & 7 & 1 & 284 & 214 & Present \\
\hline$\left[\mathrm{RuNO}(\mathrm{Py})_{4} \mathrm{~F}\right]\left(\mathrm{ClO}_{4}\right)_{2}$ & 1900 & 1762 & 1565 & 40 & 10 & 289 & 185 & 3,4 \\
\hline$\left[\mathrm{RuNO}\left(\mathrm{NH}_{3}\right)_{2} \mathrm{Py}\left(\mathrm{H}_{2} \mathrm{O}\right) \mathrm{F}\right]\left(\mathrm{ClO}_{4}\right)_{2}$ & 1923 & 1784 & 1564 & 26 & 6 & 290 & 213 & Present \\
\hline$\left[\mathrm{RuNO}\left(\mathrm{NH}_{3}\right)_{4} \mathrm{~F}\right]\left(\mathrm{SiF}_{6}\right)$ & 1902 & 1769 & 1545 & 10 & 3 & 292 & 206 & $\tau$ \\
\hline$\left[\mathrm{RuNO}\left(\mathrm{NH}_{3}\right)_{2} \mathrm{Py}\left(\mathrm{NO}_{3}\right) \mathrm{F}_{2} \mathrm{SiF}_{6} \cdot \mathrm{H}_{2} \mathrm{O}\right.$ & 1933 & 1801 & 1587 & 12 & 5 & 294 & 194 & Present \\
\hline$\left[\mathrm{RuNO}\left(\mathrm{NH}_{3}\right)_{4} \mathrm{~F}\right]\left(\mathrm{ClO}_{4}\right)_{2}$ & 1874 & 1747 & 1494 & 7 & 1 & 303 & - & 6 \\
\hline$\left[\mathrm{RuNO}\left(\mathrm{NH}_{3}\right)_{4} \mathrm{~F}\right]\left[\mathrm{PdCl}_{4}\right]$ & 1896 & 1755 & - & 1 & - & 307 & - & 6 \\
\hline
\end{tabular}

\section{References}

(1) Hirshfeld, F. L. Bonded-Atom Fragments for Describing Molecular Charge Densities. Theor. Chim. Acta 1977, 44 (2), 129-138. https://doi.org/10.1007/BF00549096.

(2) Spackman, M. A.; Jayatilaka, D. Hirshfeld Surface Analysis. CrystEngComm 2009, 11 (1), 19-32. https://doi.org/10.1039/B818330A.

(3) Kostin, G. A.; Mikhailov, A. A.; Kuratieva, N. V; Pishchur, D. P.; Makhinya, A. N. High Thermal Stability of the Ru-ON (MS1) Linkage Isomer of the Ruthenium Nitrosyl Complex [RuNO(Py) 4 F](ClO 4 ) 2 with the Trans NO-Ru-F Coordinate. New J. Chem. 2018, 42 (23), 18928-18934. https://doi.org/10.1039/C8NJ04620D.

(4) Mikhailov, A. A.; Wenger, E.; Kostin, G. A.; Schaniel, D. Room-Temperature Photogeneration of Nitrosyl Linkage Isomers in Ruthenium Nitrosyl Complexes. Chem. - A Eur. J. 2019, 25 (31), 75697574. https://doi.org/10.1002/chem.201901205.

(5) Mikhailov, A.; Vuković, V.; Kijatkin, C.; Wenger, E.; Imlau, M.; Woike, T.; Kostin, G.; Schaniel, D. Combining Photoinduced Linkage Isomerism and Nonlinear Optical Properties in Ruthenium Nitro-syl Complexes. Acta Crystallogr. Sect. B Struct. Sci. Cryst. Eng. Mater. 2019, 75 (6), 11521163. https://doi.org/10.1107/S205252061901357X.

(6) Mikhailov, A. A.; Komarov, V. Y.; Sukhikh, A. S.; Pishchur, D. P.; Schaniel, D.; Kostin, G. A. The Impact of Counterion on the Metastable State Properties of Nitrosyl Ruthenium Complexes. New J. Chem. 2020, 44 (41), 18014-18024. https://doi.org/10.1039/D0NJ04436A. 